\title{
Journal of

\section{Hit-to-Lead Optimization of Mouse Trace Amine Associated Receptor 1 (mTAAR1) Agonists with a Diphenylmethane-Scaffold: Design, Synthesis, and Biological Study}

\author{
Grazia Chiellini, ${ }^{* \dagger}{ }^{\dagger}$ Giulia Nesi, ${ }^{\ddagger}$ Simona Sestito, ${ }^{\ddagger}$ Sara Chiarugi, ${ }^{\ddagger}$ Massimiliano Runfola, ${ }^{\ddagger}$
} Stefano Espinoza, ${ }^{\S}$ Martina Sabatini, ${ }^{\dagger}$ Lorenza Bellusci, ${ }^{\dagger}$ Annunziatina Laurino, ${ }^{\prime \prime}$ Elena Cichero, ${ }^{\perp}$ Raul R. Gainetdinov, ${ }^{\#, \nabla}$ Paola Fossa, ${ }^{\perp}$ Laura Raimondi, ${ }^{\|}$Riccardo Zucchi, ${ }^{\dagger}$ and Simona Rapposelli*, ${ }^{*}$

${ }^{\dagger}$ Department of Pathology, University of Pisa, 56126 Pisa, Italy

${ }^{\ddagger}$ Department of Pharmacy, University of Pisa, 56126, Pisa, Italy

${ }^{\S}$ Department of Neuroscience and Brain Technologies, Istituto Italiano di Tecnologia, 16163 Genova, Italy

"Department of NEUROFARBA, Section of Pharmacology, University of Florence, 50139 Florence, Italy

${ }^{\perp}$ Department of Pharmacy, University of Genoa, 16126, Genoa, Italy

${ }^{\#}$ Institute of Translational Biomedicine, St. Petersburg State University, St. Petersburg, 199034, Russia

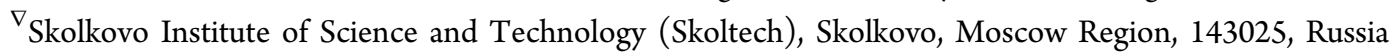

Supporting Information

ABSTRACT: The trace amine-associated receptor 1 (TAAR1) is a G-protein-coupled receptors (GPCR) potently activated by a variety of molecules besides trace amines (TAs), including thyroid hormone-derivatives like 3-iodothyronamine (T1AM), catechol-O-methyltransferase products like 3-methoxytyramine, and amphetamine-related compounds. Accordingly, TAAR1 is considered a promising target for medicinal development. To gain more insights into TAAR1 physiological functions and validation of its therapeutic potential, we recently developed a new class of thyronamine-like derivatives. Among them compound SG2 showed high affinity and potent agonist activity at mouse TAAR1. In the present work, we describe design, synthesis, and SAR study of a new series of compounds $(1-16)$ obtained by introducing specific structural changes at key points of our lead compound SG2 skeleton. Five of the newly synthesized compounds displayed mTAAR1 agonist activity higher than both SG2 and T1AM. Selected diphenylmethane analogues, namely 1 and 2, showed potent functional activity in in vitro and in vivo models.

\section{INTRODUCTION}

Thyronamine (TAM) is generally used to indicate a class of endogenous compounds deriving from thyroid hormones through metabolic reactions such as deiodination and decarboxylation. ${ }^{1}$ Over the past decade, thyronamines have been recognized as ligands of trace amine associated receptor 1 (TAAR1), and to date they represent a thriving research field. Currently, only two compounds that belong to the class of TAM have been identified in vivo: the 3-iodothyronamine (T1AM) and the thyronamine (T0AM). These compounds have been postulated to derive from thyroid hormone (T4) through deiodination and decarboxylation. T1AM is widely expressed in various tissues, such as brain, liver, heart, and blood, and it seems to be the most abundant thyronamine present in circulation. ${ }^{2}$

Among several potential receptors, it has been proved that T1AM binds to TAAR1, a G-protein coupled receptor (GPCR) that has been identified in specific areas of the central nervous system and in some peripheral areas. The binding of T1AM to TAAR1 receptor leads to increase of cAMP levels by the activation of the adenylate cyclase. Further studies also highlighted that T1AM interact with other targets such as the biogenic amines transporters and the apoB100 protein. Thyronamines, and in particular T1AM, produce different functional effects although their physiological role still remains unclear. Among the most significant effects attributed to T1AM are a hypothermic as well as negative inotropic and chronotropic cardiac effects. Moreover, endocrine and metabolic effects such as the modulation of insulin secretion, the inhibition of catecholamines resorption at the neuronal level, and an increased metabolism of lipids at the expense of that of

Received: July 22, 2016

Published: October 12, 2016 
carbohydrates have been also described. ${ }^{3}$ The wide variety of functions attributed to T1AM makes this molecule a potentially useful tool for the treatment of many diseases such as obesity, neuropsychiatric disorders, and cancer. Unfortunately, TAMs are rapidly metabolized by different enzyme systems such as amino-oxidase (MAO, SSAO), deiodinase (DIO3), sulfotransferase (SULT1A1 and SULT1A3), N-acetyltransferase, and glucuronidase. The action of these enzymes is a limit to their therapeutic use. Consequently, the great therapeutic potential as well as the lack of new useful tools to elucidate the physiological function of T1AM have pushed medicinal chemists to develop new synthetic analogues of T1AM.

Recently, with the aim of increasing the number of selective ligands for TAAR1 receptor and provide new tools to facilitate the understanding of the physiological functions of this receptor, we reported the design and synthesis of a new class of thyronamine-like compounds with a diphenylmethane scaffold, which proved to be synthetically more accessible than endogenous T1AM and T0AM. ${ }^{4,5}$ Within the small series of analogues previously synthesized, SG1 and SG2 were found to activate mouse TAAR1 receptor (mTAAR1) with a potency comparable to the corresponding endogenous ligands ${ }^{4}$ (Figure 1). In particular, SG2, the analogue of T1AM, showed an $\mathrm{EC}_{50}$<smiles>NCCc1ccc(Oc2ccc(O)cc2)c(I)c1</smiles>

T1AM

mTAAR1 $\mathrm{EC}_{50}=189 \mathrm{nM}$

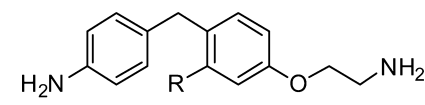

SG1 R=H

mTAAR1 $\mathrm{EC}_{50}=1700 \mathrm{nM}$ SG2 R=Me

mTAAR1 $\mathrm{EC}_{50}=240 \mathrm{nM}$
Figure 1. Structure of T1AM and the lead molecules SG1 and SG2 with a diphenylmethane molecular scaffold.
$=240 \mathrm{nM}$ comparable to T1AM $\left(\mathrm{EC}_{50}=189 \mathrm{nM}\right)$. To expand the SAR study for this new class of compounds, in the present work we describe the design and synthesis of compounds 1-16 obtained by introducing specific structural changes at key points of our lead compound SG2 skeleton. The structural optimization process of the new thyronamine-like compounds was based on molecular docking studies that highlighted the main differences in the interaction between the endogenous ligand T1AM or the synthetic analogue SG2 with the mTAAR1 receptor binding site. The newly designed compounds were first screened in vitro for mTAAR1 activation. Five compounds $(1,2,4,7$, and 8) showed a higher potency than the lead molecule SG2, as well as the endogenous ligand T1AM, with 1 and 2 being the most potent of the new series. These compounds were then evaluated both in vitro and in vivo to characterize their ability to modulate plasma glucose levels.

\section{RESULTS}

Design of New Thyronamine-Like Analogues. In our previous work, we explored the pharmacological profile of a new series of $\mathrm{T}_{1} \mathrm{AM}$ diphenylmethane analogues, and among these compounds SG1 and SG2 were found to be a good mimic of the corresponding endogenous ligands TOAM and T1AM, ${ }^{4}$ respectively. In addition, a docking study was performed to investigate the main differences between T1AM and the lead diphenylmethane analogue SG2 on mTAAR1 receptor binding. According to this study, T1AM appears to be highly stabilized in the binding site through the formation of two H-bonds between the protonated amino group of the ethylamine side chain and aspartic acid 102 (D102) and tyrosine 291 (Y291). Furthermore, T1AM established an additional H-bond between the hydroxyl-group on the outer ring and arginine 82 (R82), while no significant amino acid interactions were observed for the biaryl-ethereal oxygen of T1AM. Notably, the SG2 derivative appeared to share most of the main mTAAR1/ T1AM interactions. ${ }^{4}$ Interestingly, the replacement of the

Scheme $1^{a}$

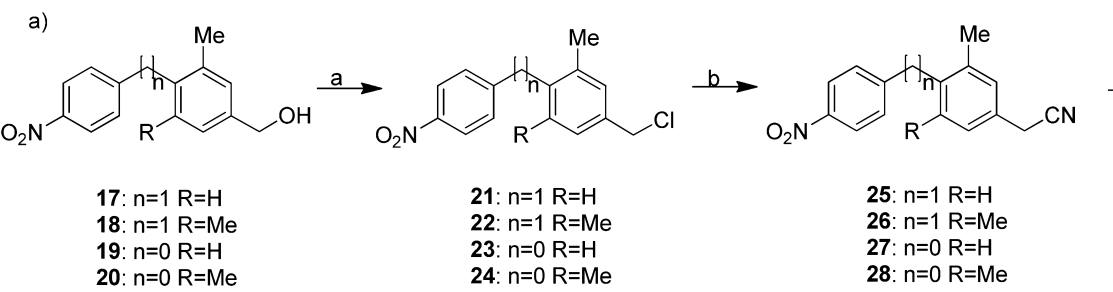<smiles></smiles>
19: $n=0 R=H$ 24: $n=0 \mathrm{R}=\mathrm{Me}$

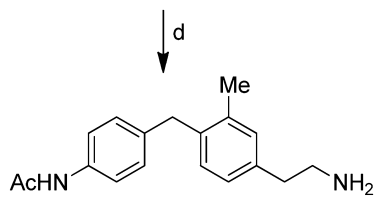

3

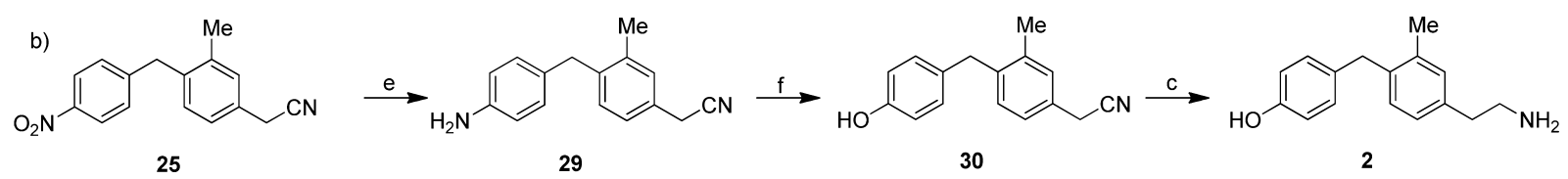

${ }^{a}$ Reagents and conditions: (a) $\mathrm{SOCl}_{2}, \mathrm{CHCl}_{3}, \mathrm{rt}, 2 \mathrm{~h}$; (b) $\mathrm{NaCN}, \mathrm{H}_{2} \mathrm{O} / \mathrm{CH}_{3} \mathrm{CN}$, mw; (c) $\mathrm{LiAlH}_{4}, \mathrm{AlCl}_{3}, \mathrm{THF}, \mathrm{reflux}, 12 \mathrm{~h}$; (d) Ac 2 O/NaHCO 3 , rt, 1 h; (e) $\mathrm{H}_{2}$, Pd-C, $\mathrm{AcOH}, 12 \mathrm{~h}$; (f) $\mathrm{NaNO}_{2}, \mathrm{H}_{2} \mathrm{SO}_{4}, \mathrm{H}_{2} \mathrm{O}, 100{ }^{\circ} \mathrm{C}, 1 \mathrm{~h}$. 
Scheme $2^{a}$<smiles>COCc1cc(OC)cc(C)c1Br</smiles>

${ }^{a}$ Reagents and conditions: (a) 4-nitrobenzyl bromide, $\mathrm{K}_{2} \mathrm{CO}_{3}, \mathrm{PdCl}_{2}$, acetone $/ \mathrm{H}_{2} \mathrm{O}$, rt, $72 \mathrm{~h}$; (b) $\mathrm{BBr}_{3}, \mathrm{DCM}, 0{ }^{\circ} \mathrm{C}, 1 \mathrm{~h} ;(\mathrm{c}) \mathrm{BrCH} \mathrm{CN} \mathrm{DMF}$, $\mathrm{Cs}_{2} \mathrm{CO}_{3}$, rt, $30 \mathrm{~h}$; (d) $\mathrm{LiAlH}_{4}, \mathrm{AlCl}_{3}$, THF, reflux, $12 \mathrm{~h}$.

Scheme $3^{a}$

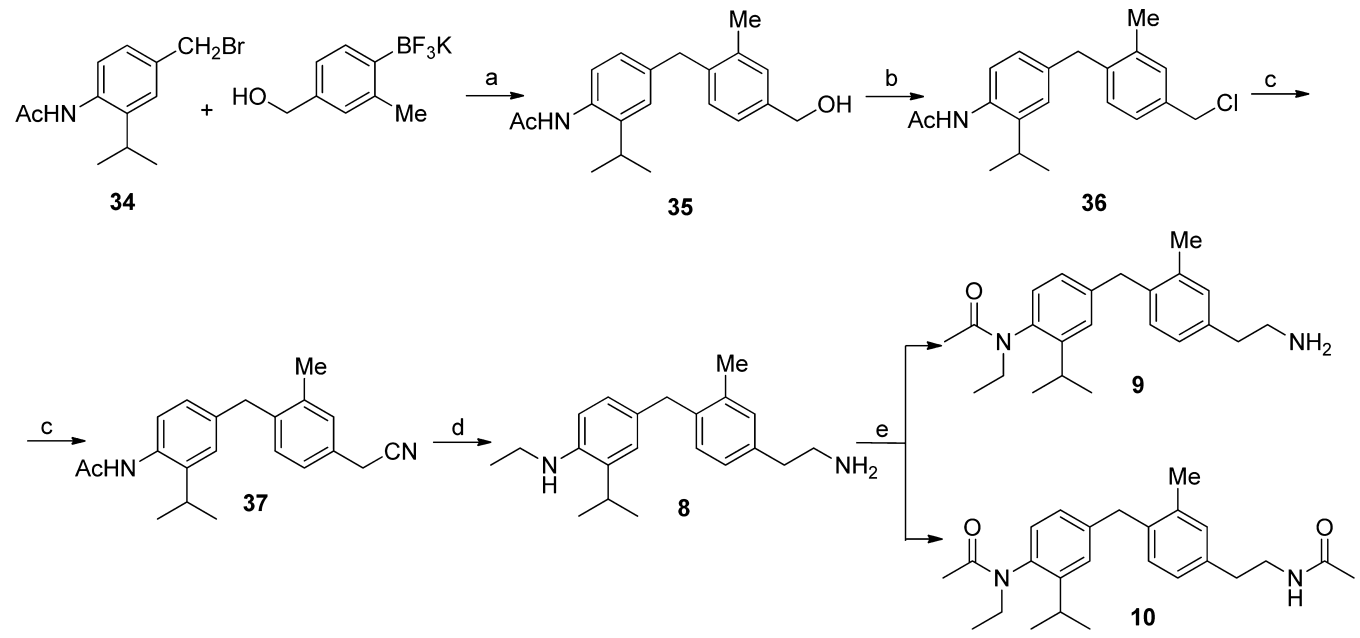

${ }^{a}$ Reagents and conditions: (a) $\mathrm{PdCl}_{2}$ dppf, $\mathrm{Cs}_{2} \mathrm{CO}_{3}, \mathrm{H}_{2} \mathrm{O} /$ dioxane, $95{ }^{\circ} \mathrm{C}, 24 \mathrm{~h}$; (b) $\mathrm{SOCl}_{2}, \mathrm{CHCl}_{3}, \mathrm{rt}, 2 \mathrm{~h}$; (c) $\mathrm{NaCN}, \mathrm{H}_{2} \mathrm{O} / \mathrm{CH}_{3} \mathrm{CN}, \mathrm{mw}$; () $\mathrm{LiAlH}_{4}, \mathrm{AlCl}_{3}, \mathrm{THF}$, reflux, $12 \mathrm{~h}$; (e) $\mathrm{Ac}_{2} \mathrm{O} / \mathrm{NaHCO}_{3}, \mathrm{rt}, 1 \mathrm{~h}$.

hydroxyl group on the T1AM outer ring with an amino group, as in SG2, allowed the formation of a cation $-\pi$ interaction, while no $\mathrm{H}$-bonds to the $\mathrm{R} 82$ backbone oxygen atom were observed. Conceivably, the oxygen atom in the SG2-inner ring side chain may induce a shift of the molecule within the binding site, thus preventing the H-bond formation with R82. To expand the SAR study for this new class of thyronamine analogues, we performed specific structural changes at key points of the SG2-molecular scaffold. Initially, to restore the Hbond with R82, the oxo-ethylamino side chain of SG2 was replaced with an ethylamine one (1-6). Among these new compounds, analogue 2 was synthesized to evaluate the effects induced by the recovery of the phenolic function as in T1AM. Additionally, to gain further insights on how the pattern of substitutions modulate the SG-analogues potency as mTAAR1 agonists, we investigated the following structure modifications: (a) the introduction of small alkyl substituents ( $\mathrm{Me}, \mathrm{i}-\mathrm{Pr})$ on both outer and inner rings $(4,6-10),(b)$ the removal of the methylene bridge, producing the diaryl analogues 5 and 6 , (c) the introduction of a biguanide moiety at the oxy-alkyl side chain $(15,16)$, and finally (d) mono- and bis- $\mathrm{N}$-acetylation (3, 9-15). This last chemical modification has been suggested by a recent study conducted by Hoefig et al., ${ }^{6}$ showing that $\mathrm{O}$-acetyl and $\mathrm{N}$-acetyl derivatives of T1AM may be found in white adipose tissue and liver endogenous cells. Notably, $\mathrm{N}$-AcT1AM was also found to be an endogenous cardioactive metabolite. ${ }^{6}$ On the basis of these findings, the corresponding mono- and bis- $\mathrm{N}$-acetylated analogues of SG1 and SG2 lead compounds (i.e., 11, 12 and 13, 14, respectively) as well as the new acetylated products namely $3,9,10$, and 15, were synthesized.

Synthesis. The derivatives 1-6 in which the oxo-ethylamino side chain of SG2 has been replaced with the ethylamine one have been synthesized as reported in Scheme 1. Briefly, the products 17-20 obtained by the palladium(0)-catalyzed Suzuki-Miyaura cross-coupling reaction of the trifluoroborate salt or boronic acid with the appropriate benzyl bromide, ${ }^{4}$ reacted with $\mathrm{SOCl}_{2}$ to give benzyl chloride 21-24. Subsequently, the nucleophilic substitution with $\mathrm{NaCN}$ afforded the compound 25-28 with high yields. As previously described, ${ }^{4}$ reduction of nitrile derivative with $\mathrm{LiAlH}_{4}$ in the presence of a Lewis's acid afforded the diamine derivatives $\mathbf{1}$, 4-6. Then, the treatment of $\mathbf{1}$ with a mixture of $\mathrm{Ac}_{2} \mathrm{O} /$ $\mathrm{NaHCO}_{3}$ provided the acetylanilide 3 (Scheme 1a).

Compound 2 was obtained starting from the acetonitrile derivative 25. Reduction of the nitro-group with $\mathrm{H}_{2}$ in the presence of $10 \% \mathrm{Pd}-\mathrm{C}$ afforded the aniline 29 . The subsequent hydrolysis of the diazonium salt obtained by reaction of 29 with $\mathrm{NaNO}_{2} / \mathrm{H}_{2} \mathrm{SO}_{4}$ afforded the final product 2 (Scheme $1 \mathrm{~b}$ ).

The Suzuki-Miyaura cross-coupling reaction of the 2,6dimethyl-4-methoxy-boronic acid with the 4-nitrobenzyl bromide gave 31, which was demethylated with $\mathrm{BBr}_{3}$ at $0{ }^{\circ} \mathrm{C}$, 
Compound 1

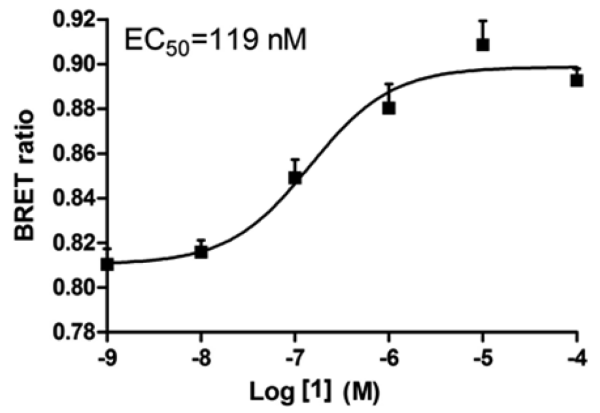

Compound 7

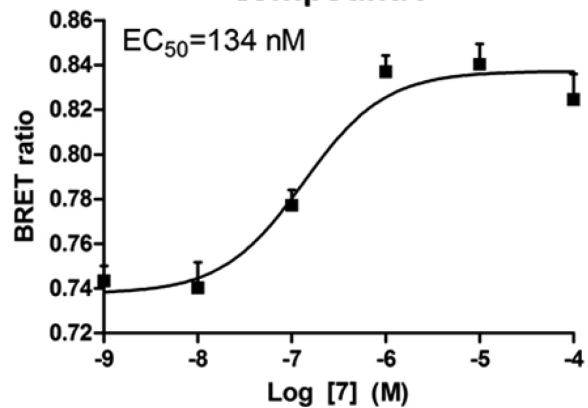

\section{Compound 2}

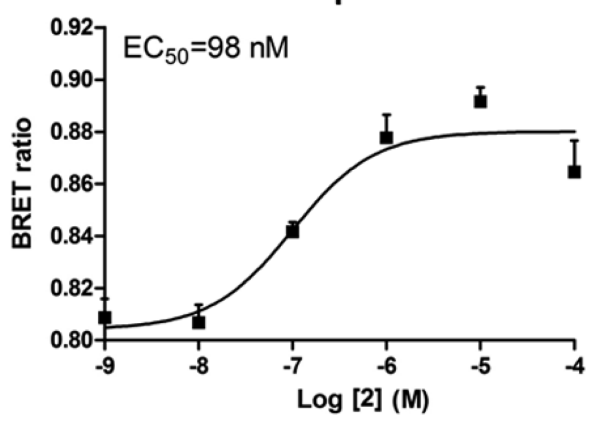

Compound 8

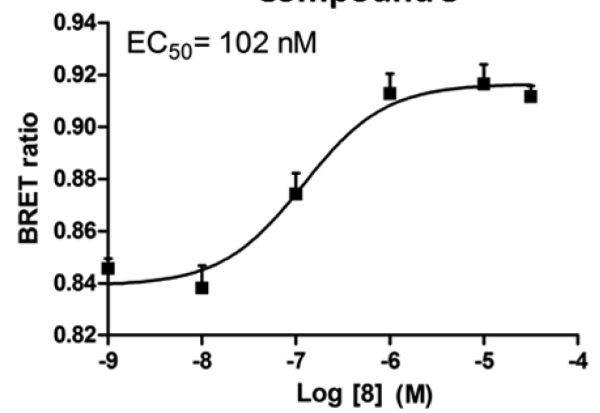

Figure 2. Dose-response curves of the most active SG2-analogues. All the compounds are full agonists (efficacy $=100 \%$ ).

affording to phenol 32. The subsequent reaction of $\alpha$-bromideacetonitrile with 32 followed by reduction to the corresponding diamine-derivative gave the superior homologue of SG2 (7) (Scheme 2).

Derivative 8-10 substituted with an i-Pr group in the outer ring and with a small $N$-alkyl $(8)$ or $N$-acetyl group $(9,10)$ were synthesized starting from the cross coupling reaction of $N$ (4-(bromomethyl)-2-isopropylphenyl)acetamide (34) (see Supporting Information, Scheme S1) and the (4-(hydroxymethyl)-2-methylphenyl)fluoroboronate salt (Scheme 3). The tandem reactions with $\mathrm{SOCl}_{2}$ and $\mathrm{NaCN}$ gave the nitrile derivative 37 with high yields. Subsequent reduction with $\mathrm{LiAlH}_{4} / \mathrm{AlCl}_{3}$ afforded the product 8, which was then reacted with $\mathrm{Ac}_{2} \mathrm{O}$ in the presence of $\mathrm{NaHCO}_{3}$ in a ratio of $1: 1$ or $1: 2$ to give 9 and 10 , respectively.

Concerning the synthesis of the mono- and $N$-diacetylated derivatives 11-14 and the biguanide analogue of SG2 (15 and 16), the synthetic pathway as well as the procedures are reported in Supporting Information (Scheme S2).

Receptor Activation. mTAAR1 is coupled to stimulatory $\mathrm{G}$ protein and thus induces cAMP production in HEK293 upon agonist exposure. We measured the activity of the new compounds using a BRET-based assay as previously reported by us. ${ }^{4,7}$ The standard TAAR1 agonist $\beta$-PEA was used as reference compound $\left(\mathrm{EC}_{50}=138 \mathrm{nM}\right)$.

Initially, all 1-16 compounds were tested at a screening concentration of $10 \mu \mathrm{M}$. Then, for the compounds that were found to be active, a dose-response curve was performed to calculate their corresponding $\mathrm{EC}_{50}$ values (Figure 2). As shown in Table 1, five compounds, namely $1,2,4,7$, and 8 , appeared to be more potent than the lead compound SG2 as well as T1AM. All of them showed to be full agonists (efficacy = $100 \%)$. In particular, the more effective structure modifications resulted from the replacement of oxy-ethylamino side chain of SG2 with the ethylamino one (1) and the concomitant replacement of the amino group of the outer ring with the
Table 1. Activity of the New Diphenylmethane Derivatives 1-6 and 8-10 Using BRET-Based Assay in mTAAR1 Transfected HEK 293 Cells $^{a}$<smiles>[Y]CCc1cc([R])c(CC(C)c2ccc([X])c([R2])c2)c([R])c1</smiles>

$1-6 ; 8-10$

$\begin{array}{cllllllr}\text { compd } & \mathrm{X} & \mathrm{n} & \mathrm{R} & \mathrm{R}_{1} & \mathrm{R}_{2} & \mathrm{Y} & \begin{array}{c}\text { mTAAR1 } \\ (\mathrm{nM})\end{array} \\ \mathbf{1} & \mathrm{NH}_{2} & 1 & \mathrm{Me} & \mathrm{H} & \mathrm{H} & \mathrm{NH}_{2} & 119 \\ \mathbf{2} & \mathrm{OH} & 1 & \mathrm{Me} & \mathrm{H} & \mathrm{H} & \mathrm{NH}_{2} & 98 \\ \mathbf{3} & \mathrm{NHAc} & 1 & \mathrm{Me} & \mathrm{H} & \mathrm{H} & \mathrm{NH}_{2} & 3100 \\ \mathbf{4} & \mathrm{NH}_{2} & 1 & \mathrm{Me} & \mathrm{Me} & \mathrm{H} & \mathrm{NH}_{2} & 158 \\ \mathbf{5} & \mathrm{NH}_{2} & 0 & \mathrm{Me} & \mathrm{H} & \mathrm{H} & \mathrm{NH}_{2} & 1180 \\ \mathbf{6} & \mathrm{NH}_{2} & 0 & \mathrm{Me} & \mathrm{Me} & \mathrm{H} & \mathrm{NH}_{2} & 633 \\ \mathbf{8} & \mathrm{NHEt}_{\mathbf{9}} & 1 & \mathrm{Me} & \mathrm{H} & \mathrm{i}-\mathrm{Pr} & \mathrm{NH}_{2} & 102 \\ \mathbf{1 0} & \text { AcNEt } & 1 & \mathrm{Me} & \mathrm{H} & \mathrm{i}-\mathrm{Pr} & \mathrm{NH}_{2} & 440 \\ & \text { AcNEt } & 1 & \mathrm{Me} & \mathrm{H} & \mathrm{i}-\mathrm{Pr} & \mathrm{NHAc} & >10000\end{array}$

${ }^{a_{T}}$ The $\mathrm{EC}_{50}$ values are expressed in $\mathrm{nM}$.

hydroxyl moiety (2). Moreover, the addition of small alkyl groups in the inner ring of SG2 (7), as well as in the outer ring of the $N$-ethyl analogue of $\mathbf{1}(\mathbf{8})$, turned out to be successful, thus obtaining new compounds with a potency 2 -fold higher than the lead compound SG2 (Table 2).

Docking Study. In our previous work, we investigated $\mathrm{T}_{1} \mathrm{AM}$ and a series of $\mathrm{T}_{1} \mathrm{AM}$ analogues whose potency profile proved to be highly related to the presence of a proper basic feature linked to an aromatic core. ${ }^{4}$ Indeed, our molecular modeling studies pointed out the relevance of a key salt bridge between the protonated amine group of SG1 and SG2 lead compounds and the highly conserved residue D102, together with a number of $\pi-\pi$ stacking and cation $-\pi$ contacts with the 
Table 2. Activity of the New Diphenylmethane Derivatives 7 and 11-16 Using BRET-Based Assay in mTAAR1 Transfected HEK 293 Cells $^{a}$

\begin{tabular}{|c|c|c|c|c|c|c|}
\hline & & & $7,11-1$ & & & \\
\hline compd & $X$ & $\mathrm{n}$ & $\mathrm{R}$ & $\mathrm{R}_{1}$ & $\mathrm{Y}$ & $\begin{array}{l}\text { mTAAR } 1 \\
\mathrm{EC}_{50}(\mathrm{nM})\end{array}$ \\
\hline 7 & $\mathrm{NH}_{2}$ & 1 & $\mathrm{Me}$ & $\mathrm{Me}$ & $\mathrm{NH}_{2}$ & 134 \\
\hline 11 & NHAc & 1 & $\mathrm{H}$ & $\mathrm{H}$ & $\mathrm{NH}_{2}$ & $>10000$ \\
\hline 12 & NHAc & 1 & $\mathrm{H}$ & $\mathrm{H}$ & NHAc & $>10000$ \\
\hline 13 & NHAc & 1 & $\mathrm{Me}$ & $\mathrm{H}$ & $\mathrm{NH}_{2}$ & $>10000$ \\
\hline 14 & NHAc & 1 & $\mathrm{Me}$ & $\mathrm{H}$ & NHAc & $>10000$ \\
\hline 15 & NHAc & 1 & $\mathrm{Me}$ & $\mathrm{H}$ & & $>10000$ \\
\hline 16 & $\mathrm{NH}_{2}$ & 1 & $\mathrm{Me}$ & $\mathrm{H}$ & & $>10000$ \\
\hline
\end{tabular}

${ }^{a_{\mathrm{T}}} \mathrm{EC}_{50}$ values are expressed in $\mathrm{nM}$.

surrounding amino acids, as we previously detected in other series of TAAR1 ligands. 8

These findings were supported by further homology modeling and docking studies we performed within the murine and human TAAR1 and TAAR5 receptors with respect to $\mathrm{T}_{1} \mathrm{AM}$ ligand $^{10}$ and were also in accordance with the key role played by a proper basic feature included in any TAAR1 ligand, as reported in literature. ${ }^{11}$ Notably, this information was definitively validated by the mutagenesis data involving the D102 residue, reported by Reese. ${ }^{12}$

To rationalize the pharmacological results and refine the computational models, in silico docking studies on the most active compounds (1, 2, 7, and 8) were also performed, analyzing their interactions with the putative receptor binding site (see Supporting Information, Table S1).

In agreement with the experimental data, our docking calculations revealed that the presence of the ethylamine chain appears to be the most effective choice, in particular within those series of compounds bearing a mono methyl-substituted inner ring $(1,2$, and 8$)$. On the basis of a comparison with the prototype T1AM, the most promising newly designed analogues were overturned within the receptor binding site, maintaining in any case the key contact with D102 which is required for TAAR1 agonism (see Supporting Information, Figure $\mathrm{S} 1)^{12}$
Notably, the most effective compounds $\mathbf{1}$ and $\mathbf{2}$ were characterized by a reversed docking mode when compared to that previously described for SG2. ${ }^{4}$ Briefly, we originally highlighted the key role played by the protonated amino group of the ethyloxyamine side chain of SG2 in H-bonding with D102 and Y291, while the inner-phenyl group was engaged in $\pi-\pi$ stacking with Y287. On the contrary, 1 (and 2) displayed one $\mathrm{H}$-bond between the aniline portion in the outer ring (or the hydroxyl group) and the D102 negatively charged side chain, while the protonated basic side chain appeared to be involved in one H-bond and in a salt bridge with T83 and D284, respectively, as shown in parts a and b of Figure 3, respectively.

The addition of a methyl group in the inner ring of SG2 led to a 2-fold increase of potency for 7, with an $\mathrm{EC}_{50}$ of $134 \mathrm{vs} 240$ $\mathrm{nM}$ for SG2. The docking study showed that also 7 takes an overturned positioning with respect to SG2 in the binding site of mTAAR1 (Figure 3c). Presumably, the presence of an additional substituent into the inner ring causes a shift of the molecule within the binding site, promoting the interaction of the aniline nitrogen atom in the outer ring with $\mathrm{D} 102$ residue while the side chain's nitrogen atom interacts with D284.

Finally, the introduction of small alkyl groups into the outer ring of $\mathbf{1}$ as in compound $\mathbf{8}$ did not prevent the interaction between the nitrogen atom of aniline with D102 residue. 
a

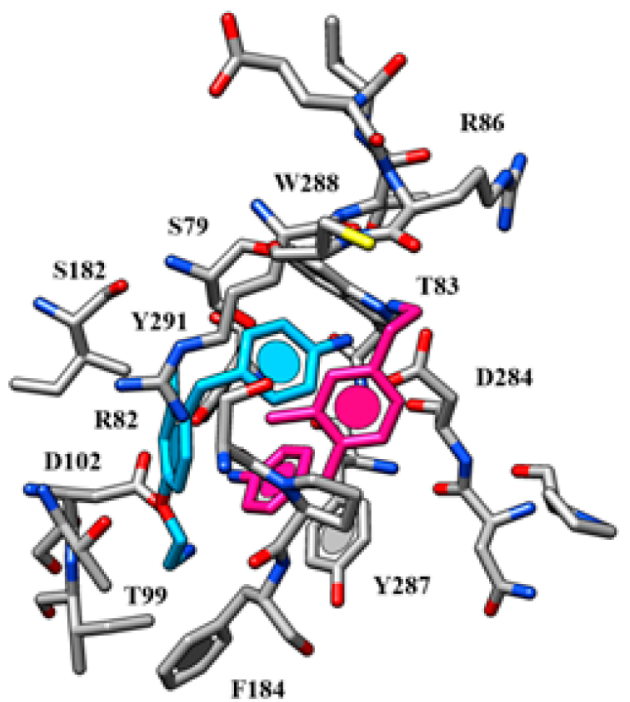

c

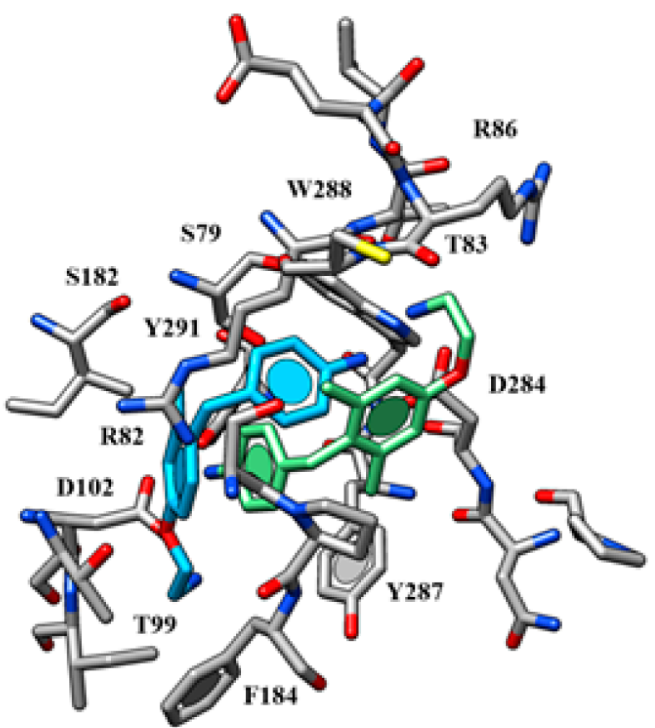

b
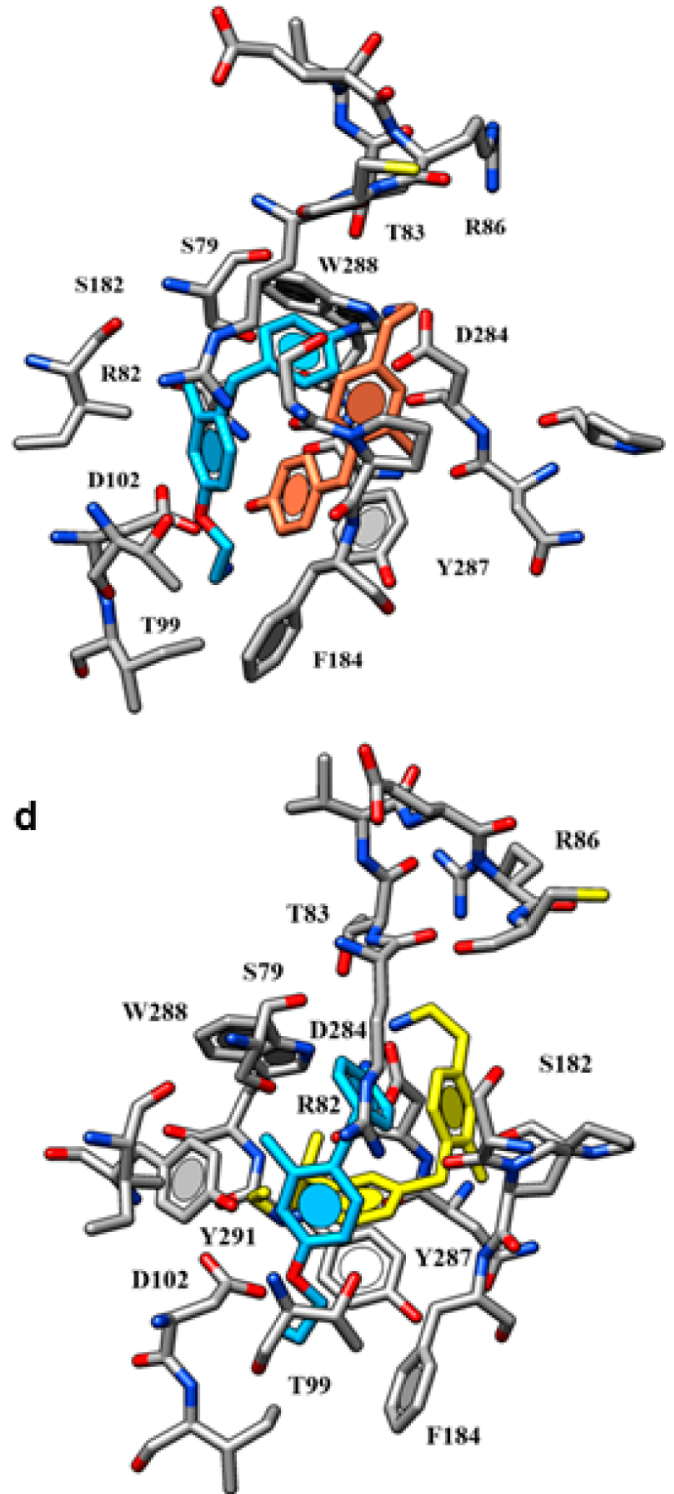

Figure 3. Docking mode of compounds SG2 (C atom cyan) and (a) 1 (C atom deep magenta), (b) 2 (C atom; coral), (c) 7 (C atom; light green), and (d) 8 ( $\mathrm{C}$ atom; yellow) at the murine TAAR1 binding site. The most important residues are labeled.

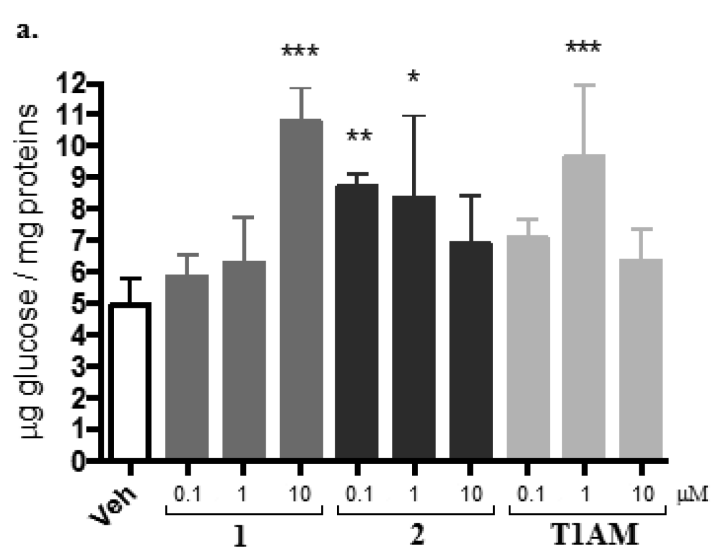

b.

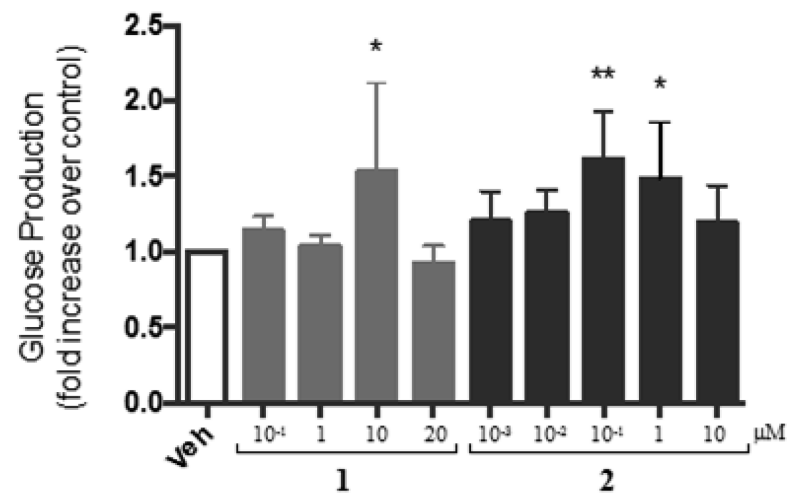

Figure 4. (a) Glucose production in HepG2 cell cultures that were incubated for $4 \mathrm{~h}$ in glucose production buffer after adding vehicle (DMSO) or compounds 1, 2, and T1AM. Results are expressed as mean \pm SEM and are normalized to the total cell protein content determined in cell lysates $(n$ $=3$ in each case). (b) Glucose production in HepG2 cell in response to increasing concentrations of compounds $\mathbf{1}(0.1,1,10$, and $20 \mu \mathrm{M})$ and 2 $(0.001,0.01,0.1,1$, and $10 \mu \mathrm{M})$. Results are mean \pm SEM and are normalized to the total cell protein content determined in cell lysates. $(n=6$ in each case). $* P<0.05, * * P<0.01, * * * P<0.001$ by ANOVA. 
Indeed, the $\mathrm{EC}_{50}$ value of $\mathbf{8}\left(\mathrm{EC}_{50}=102 \mathrm{nM}\right)$ was comparable to that of $1\left(\mathrm{EC}_{50}=119 \mathrm{nM}\right)$.

Modulation of Hepatic Glucose Production. The hyperglycemic effect observed after administration of exogenous T1AM had previously been attributed only to a modulation of insulin and/or glucagone secretion. ${ }^{13-15}$ Recently, our study ${ }^{16}$ showed that in human hepatocarcinoma cells (HepG2) T1AM treatment directly stimulated glucose production $\left(\mathrm{EC}_{50}=0.84 \mu \mathrm{M}\right)$ if adequate gluconeogenetic substrates were provided. Interestingly, the effect of T1AM on gluconeogenesis displayed a bell-shaped dose-response curve, suggesting a biphasic effect of T1AM on the modulation of gluconeogenesis. In the present study, the effects induced by two of the most potent new mTAAR1 agonists (i.e., 1 and 2) on gluconeogenesis were assessed. Preliminarily, HepG2 cells were incubated with each compound at three different doses (0.1, 1, and $10 \mu \mathrm{M})$. By comparison, similar experiments were performed using T1AM. As shown in Figure 4a, incubation with 0.1 and $1 \mu \mathrm{M}$ of compound 2 induced a significant increase in glucose production $(P<0.01)$, while a dose of 10 $\mu \mathrm{M}$ induced a decreased stimulation of glucose production. On the other hand, compound $\mathbf{1}$ showed a dose-dependent increase of glucose production, which reached statistical significance only when compound $\mathbf{1}$ was used at the highest dose $(10 \mu \mathrm{M})$. As shown in Figure $4 \mathrm{a}$, treatment of HepG2 cells with T1AM $(0.1,1$, and $10 \mu \mathrm{M})$ confirmed the bell-shaped dose-response curve observed in our previous study. ${ }^{16}$ To better define the dose dependence of $\mathbf{1}$ and $\mathbf{2}$ effects on glucose production, additional experiments were carried out using a wider range of doses for both compounds. As shown in Figure $4 \mathrm{~b}$, the $\mathrm{EC}_{50}$ calculated for the effect on gluconeogenesis was in the submicromolar range for 2 , and in the supramicromolar range for 1 .

Modulation of Plasma Glucose Level. As previously reported by us, thyronamine-like analogues SG1 and SG2 demonstrated the ability to increase plasma glycaemia with a potency comparable to that of the corresponding endogenous thyronamine (i.e., T0AM and T1AM). ${ }^{4}$ Thus, in the present work, the effects induced by $\mathbf{1}$ and $\mathbf{2}$ derivatives on plasma glucose level were also assessed.

Figure 5 shows that a single low dose $(4.0 \mu \mathrm{g} / \mathrm{kg}$, ip) of 1 or 2 significantly increases plasma glycaemia in CD-1 mice with a potency comparable to that previously shown by lead compound SG2.

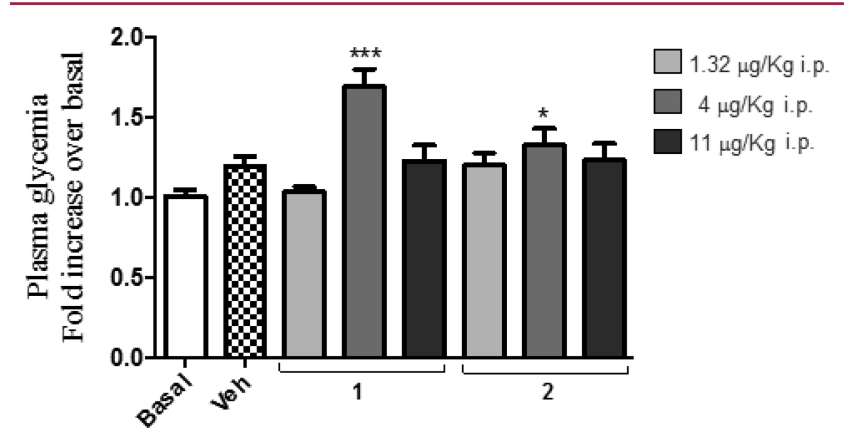

Figure 5. Effect of 1 and 2 on plasma glycaemia $\left(\mathrm{mg} \cdot \mathrm{L}^{-1}\right)$ in CD1mice. Plasma glucose was measured $15 \mathrm{~min}$ after test compound or vehicle injection (ip) in blood collected from the tail veins of $4 \mathrm{~h}$ starved mice ( $n=8$ in each group). Results are expressed as means mean \pm SEM. $* P<0.05$ vs vehicle. ${ }^{*} * * P<0.001$ vs vehicle.

\section{CONCLUSION}

Our ongoing efforts to develop thyronamine-like analogues synthetically more accessible than endogenous thyronamines yielded a new class of potent mTAAR1 diphenylmethane ligands.

A medicinal chemistry optimization combined to docking studies were used starting from the molecular scaffold of our recently developed SG-compounds to design the new ligands. In particular, we investigated: (i) the replacement of the oxyethylamino side chain of SG2 with an ethylamino one, (ii) the introduction of small alkyl substituents $(\mathrm{Me}, \mathrm{i}-\mathrm{Pr})$ on both outer and inner rings, and (iii) the recovery of the phenolic function as in T1AM. Overall these chemical modifications resulted in more potent mTAARl agonists when compared to T1AM, as well as lead compound SG2. Taking into account the high structure similarity of compounds $\mathbf{1}$ and $\mathbf{2}$ with T1AM and their high affinity for mTAAR1, we further investigated their ability to modulate glucose levels using both in vitro (human HepG2 cells) and in vivo (CD1-mice) models. Both compounds demonstrated potent functional activity. In conclusion, this paper describes for the first time the successful outcome of a hit-to-lead optimization process, leading to the identification of new tools to explore the physiological and pharmacological functions of TAAR1.

\section{EXPERIMENTAL SECTION}

Chemistry. General Material and Methods. Melting points were determined on a Kofler hot-stage apparatus and are uncorrected. Chemical shifts $(\delta)$ are reported in parts per million downfield from tetramethylsilane and referenced from solvent references; coupling constants $J$ are reported in hertz. ${ }^{1} \mathrm{H}$ NMR and ${ }^{13} \mathrm{C}$ NMR spectra of all compounds were obtained with a Bruker TopSpin $3.2400 \mathrm{MHz}$ spectrometer. ${ }^{13} \mathrm{C}$ NMR spectra were fully decoupled. The following abbreviations are used: singlet $(\mathrm{s})$, doublet $(\mathrm{d})$, triplet $(\mathrm{t})$, doubledoublet (dd), and multiplet $(\mathrm{m})$. The elemental compositions of the compounds agreed to within $\pm 0.4 \%$ of the calculated values. Chromatographic separation was performed on silica gel columns by flash (Kieselgel 40, 0.040-0.063 mm; Merck) or gravity column (Kieselgel 60, 0.063-0.200 mm; Merck) chromatography. The $\geq 95 \%$ purity of the tested compounds was confirmed by combustion analysis. Reactions were followed by thin-layer chromatography (TLC) on Merck aluminum silica gel $\left(60 \mathrm{~F}_{254}\right)$ sheets that were visualized under a UV lamp. The microwave-assisted procedures were carried out with a CEM Discover LabMate microwave. Evaporation was performed in vacuo (rotating evaporator). Sodium sulfate was always used as the drying agent. Commercially available chemicals were purchased from Sigma-Aldrich.

4-(4-(2-Aminoethyl)-2-methylbenzyl)aniline (1). To a suspension of $\mathrm{LiAlH}_{4}(4.80 \mathrm{~mL}, 4.80 \mathrm{mmol})$ in THF was added dropwise a solution of $\mathrm{AlCl}_{3}(639.6 \mathrm{mg}, 4.80 \mathrm{mmol})$ in THF $(20 \mathrm{~mL})$, and the mixture was stirred for $5 \mathrm{~min}$ at rt. A solution of $25(142.0 \mathrm{mg}, 0.53$ $\mathrm{mmol}$ ) in THF was added dropwise, and the mixture was heated at reflux for $12 \mathrm{~h}$. The mixture was cooled to $0{ }^{\circ} \mathrm{C}$ with an ice bath and added dropwise with water and then with $10 \%$ aqueous $\mathrm{HCl}$. The mixture was extracted with diethyl ether, and the aqueous layer was made alkaline with $\mathrm{NaOH} 2 \mathrm{~N}$ and extracted with $\mathrm{CHCl}_{3}$. The organic phase was separated, washed with brine, dried, filtered, and concentrated. The crude was purified by conversion in the corresponding hydrochloride salt. White solid; $\mathrm{mp} 153-157{ }^{\circ} \mathrm{C}$ (67\% yield). ${ }^{1} \mathrm{H}$ NMR ( $\left.\mathrm{CD}_{3} \mathrm{OD}\right): \delta 2.21\left(\mathrm{~s}, 3 \mathrm{H}, \mathrm{CH}_{3}\right), 2.94(\mathrm{t}, 2 \mathrm{H}, J=$ $\left.7.8 \mathrm{~Hz}, \mathrm{CH}_{2}\right), 3.17\left(\mathrm{t}, 2 \mathrm{H}, J=7.8 \mathrm{~Hz}, \mathrm{CH}_{2}\right), 4.03\left(\mathrm{~s}, 2 \mathrm{H}, \mathrm{CH}_{2}\right), 7.07-$ $7.15(\mathrm{~m}, 3 \mathrm{H}, \mathrm{Ar}), 7.29(\mathrm{~d}, 2 \mathrm{H}, J=8.4 \mathrm{~Hz}, \mathrm{Ar}), 7.34(\mathrm{~d}, 2 \mathrm{H}, J=8.4 \mathrm{~Hz}$, Ar) ppm. ${ }^{13} \mathrm{C}$ NMR (CD $\left.\mathrm{OD}\right): \delta 143.44,138.48,138.37,136.40$, $131.89,131.66,131.35,129.71,127.54,124.11,41.99,39.31,34.09$, 19.70 ppm. Anal. $\left(\mathrm{C}_{16} \mathrm{H}_{20} \mathrm{~N}_{2} \cdot \mathrm{HCl}\right) \mathrm{C}, \mathrm{H}, \mathrm{N}$. \% Calcd: 79.96 (C); 8.39 $(\mathrm{H}) ; 11.66(\mathrm{~N})$. \% Found: $79.88(\mathrm{C}) ; 8.55(\mathrm{H}) ; 11.42(\mathrm{~N})$. 
4-(4-(2-Aminoethyl)-2-methylbenzyl)phenol (2). Compound 2 was synthesized from $30(109 \mathrm{mg}, 0.46 \mathrm{mmol}), \mathrm{LiAlH}_{4}(4.13 \mathrm{~mL}$, $4.13 \mathrm{mmol})$, and $\mathrm{AlCl}_{3}(550.8 \mathrm{mg}, 4.13 \mathrm{mmol})$ in THF $(18 \mathrm{~mL})$ following the same procedure described above for the preparation of 1 . Yellow solid; mp $138-140{ }^{\circ} \mathrm{C}$ ( $30 \%$ yield). ${ }^{1} \mathrm{H}$ NMR $\left(\mathrm{CD}_{3} \mathrm{OD}\right): \delta$ $2.18\left(\mathrm{~s}, 3 \mathrm{H}, \mathrm{CH}_{3}\right), 2.70\left(\mathrm{t}, 2 \mathrm{H}, J=7.2 \mathrm{~Hz}, \mathrm{CH}_{2}\right), 2.87(\mathrm{t}, 2 \mathrm{H}, J=7.2$ $\left.\mathrm{Hz}, \mathrm{CH}_{2}\right), 3.81\left(\mathrm{~s}, 2 \mathrm{H}, \mathrm{CH}_{2}\right), 6.64(\mathrm{~d}, 2 \mathrm{H}, J=8.4 \mathrm{~Hz}, \mathrm{Ar}), 6.84(\mathrm{~d}, 2 \mathrm{H}$, $J=8.4 \mathrm{~Hz}, \mathrm{Ar}), 6.94-7.03$ (m, 3H, Ar) ppm. ${ }^{13} \mathrm{C}$ NMR (CD $\left.\mathrm{OD}\right): \delta$ 146.29, 139.28, 137.93, 137.82, 131.69, 131.64, 131.10, 130.31, 127.21, 116.88, 54.79, 39.22, 38.30, 19.74 ppm. Anal. $\left(\mathrm{C}_{16} \mathrm{H}_{19} \mathrm{NO}\right) \mathrm{C}, \mathrm{H}, \mathrm{N} . \%$ Calcd: $79.63(\mathrm{C}) ; 7.94(\mathrm{H}) ; 5.80(\mathrm{~N})$. \% Found: $79.77(\mathrm{C}) ; 7.81(\mathrm{H})$; $5.92(\mathrm{~N})$.

$\mathrm{N}$-(4-(4-(2-Aminoethyl)-2-methylbenzyl)phenyl)acetamide (3). To a solution of $1(50 \mathrm{mg}, 0.18 \mathrm{mmol})$ in saturated $\mathrm{NaHCO}_{3}$ solution $(0.06 \mathrm{~mL})$ was added $\mathrm{Ac}_{2} \mathrm{O}(0.02 \mathrm{~mL}, 0.18 \mathrm{mmol})$. The mixture was left stirring at $\mathrm{rt}$ for $1 \mathrm{~h}$, and then the mixture was dissolved in water and extracted with $\mathrm{CHCl}_{3}$. The organic layer was dried and concentrated under reduced pressure. The crude product was purified by precipitation from $\mathrm{MeOH} / \mathrm{Et}_{2} \mathrm{O}$ to give 3. White solid;mp $132-136{ }^{\circ} \mathrm{C}$ (60\% yield). ${ }^{1} \mathrm{H}$ NMR $\left(\mathrm{CD}_{3} \mathrm{OD}\right): \delta 2.10$ (s, $\left.3 \mathrm{H}, \mathrm{CH}_{3}\right), 2.20\left(\mathrm{~s}, 3 \mathrm{H}, \mathrm{COCH}_{3}\right), 2.92\left(\mathrm{t}, 2 \mathrm{H}, J=7.7 \mathrm{~Hz}, \mathrm{CH}_{2}\right), 3.15$ $\left(\mathrm{t}, 2 \mathrm{H}, J=7.7 \mathrm{~Hz}, \mathrm{CH}_{2}\right), 3.91\left(\mathrm{~s}, 2 \mathrm{H}, \mathrm{CH}_{2}\right), 7.04(\mathrm{~d}, 2 \mathrm{H}, J=8.4 \mathrm{~Hz}$, $\mathrm{Ar}$ ), $7.05-7.11(\mathrm{~m}, 3 \mathrm{H}, \mathrm{Ar}), 7.34(\mathrm{~d}, 2 \mathrm{H}, J=8.4 \mathrm{~Hz}, \mathrm{Ar}) \mathrm{ppm} .{ }^{13} \mathrm{C}$ NMR $\left(\mathrm{CD}_{3} \mathrm{OD}\right): \delta 171.57,139.37,138.31,137.77,137.62,135.91$, 131.71, 131.52, 129.93, 127.33, 121.33, 42.01, 39.37, 34.09, 23.77, 19.74 ppm. Anal. $\left(\mathrm{C}_{16} \mathrm{H}_{20} \mathrm{~N}_{2} \cdot \mathrm{HCl}\right) \mathrm{C}, \mathrm{H}, \mathrm{N} . \%$ Calcd: 79.96 (C); 8.39 $(\mathrm{H}) ; 11.66(\mathrm{~N})$. \% Found: $79.88(\mathrm{C}) ; 8.55(\mathrm{H}) ; 11.42(\mathrm{~N})$.

4-(4-(2-Aminoethyl)-2,6-dimethylbenzyl)aniline (4). Compound 4 was synthesized from 26 (109 mg, $0.46 \mathrm{mmol}), \mathrm{LiAlH}_{4}(4.13 \mathrm{~mL}, 4.13$ $\mathrm{mmol})$, and $\mathrm{AlCl}_{3}(550.8 \mathrm{mg}, 4.13 \mathrm{mmol})$ in THF $(18 \mathrm{~mL})$ following the same procedure described above for the preparation of 1 . The crude was purified by conversion in the corresponding hydrochloride salt. White solid; mp $143-145{ }^{\circ} \mathrm{C}$ ( $68 \%$ yield). ${ }^{1} \mathrm{H}$ NMR ( $\left.\mathrm{CD}_{3} \mathrm{OD}\right): \delta$ $2.22\left(\mathrm{~s}, 6 \mathrm{H}, \mathrm{CH}_{3}\right), 2.91\left(\mathrm{t}, 2 \mathrm{H}, J=7.7 \mathrm{~Hz}, \mathrm{CH}_{2}\right), 3.18(\mathrm{t}, 2 \mathrm{H}, J=7.7$ $\left.\mathrm{Hz}, \mathrm{CH}_{2}\right), 4.11\left(\mathrm{~s}, 2 \mathrm{H}, \mathrm{CH}_{2}\right), 7.01(\mathrm{~s}, 2 \mathrm{H}, \mathrm{Ar}), 7.17(\mathrm{~d}, 2 \mathrm{H}, J=8.6 \mathrm{~Hz}$, $\mathrm{Ar}), 7.30$ (d, $2 \mathrm{H}, J=8.6 \mathrm{~Hz}, \mathrm{Ar}) \mathrm{ppm} .{ }^{13} \mathrm{C}$ NMR $\left(\mathrm{CD}_{3} \mathrm{OD}\right): \delta 142.77$, $138.85,136.31,136.14,130.58,129.68,129.61,124.13,42.00,34.98$, 34.12, 20.23 ppm. Anal. $\left(\mathrm{C}_{17} \mathrm{H}_{22} \mathrm{~N}_{2} \cdot \mathrm{HCl}\right) \mathrm{C}, \mathrm{H}, \mathrm{N} . \%$ Calcd: 80.27 (C); $8.72(\mathrm{H}) ; 11.01(\mathrm{~N})$. \% Found: $80.40(\mathrm{C}) ; 8.59(\mathrm{H}) ; 11.31(\mathrm{~N})$.

4'-(2-Aminoethyl)-2'-methyl-[1,1'-biphenyl]-4-amine (5). Compound 5 was synthesized from $27(109 \mathrm{mg}, 0.46 \mathrm{mmol}), \mathrm{LiAlH}_{4}$ $(4.13 \mathrm{~mL}, 4.13 \mathrm{mmol})$, and $\mathrm{AlCl}_{3}(550.8 \mathrm{mg}, 4.13 \mathrm{mmol})$ in THF (18 $\mathrm{mL}$ ) following the same procedure described above for the preparation of 1 . The crude was purified by conversion in the corresponding hydrochloride salt. White solid; mp $165-167{ }^{\circ} \mathrm{C}$ (70\% yield). ${ }^{1} \mathrm{H}$ NMR ( $\left.\mathrm{CD}_{3} \mathrm{OD}\right): \delta 2.25\left(\mathrm{~s}, 3 \mathrm{H}, \mathrm{CH}_{3}\right), 2.99\left(\mathrm{t}, 2 \mathrm{H}, J=7.8 \mathrm{~Hz}, \mathrm{CH}_{2}\right)$, $3.22\left(\mathrm{t}, 2 \mathrm{H}, J=7.8 \mathrm{~Hz}, \mathrm{CH}_{2}\right), 7.19(\mathrm{~d}, 2 \mathrm{H}, J=1.2 \mathrm{~Hz}, \mathrm{Ar}), 7.25(\mathrm{~s}, 1 \mathrm{H}$, $\mathrm{Ar})$, 7.51-7.46 (m, 4H, Ar) ppm. ${ }^{13} \mathrm{C}$ NMR $\left(\mathrm{CD}_{3} \mathrm{OD}\right): \delta 144.11$, $140.55,137.72$, 137.02, 131.99, 131.21, 130.72, 127.48, 124.08, 41.92, 34.19, 20.43 ppm. Anal. $\left(\mathrm{C}_{15} \mathrm{H}_{18} \mathrm{~N}_{2} \cdot \mathrm{HCl}\right) \mathrm{C}, \mathrm{H}, \mathrm{N} . \%$ Calcd: 79.61 (C); $8.02(\mathrm{H}) ; 12.38(\mathrm{~N})$. \% Found: $80.00(\mathrm{C}) ; 8.10(\mathrm{H}) ; 12.22(\mathrm{~N})$.

4'-(2-Aminoethyl)-2',6'-dimethyl-[1,1'-biphenyl]-4-amine (6). Compound 6 was synthesized from 28 (109 $\mathrm{mg}, 0.46 \mathrm{mmol})$, $\mathrm{LiAlH}_{4}(4.13 \mathrm{~mL}, 4.13 \mathrm{mmol})$, and $\mathrm{AlCl}_{3}(550.8 \mathrm{mg}, 4.13 \mathrm{mmol})$ in THF $(18 \mathrm{~mL})$ following the same procedure described above for the preparation of 1 . The crude was purified by conversion to the corresponding hydrochloride salt. White solid; mp $171-173{ }^{\circ} \mathrm{C}(73 \%$ yield). ${ }^{1} \mathrm{H}$ NMR ( $\left.\mathrm{CD}_{3} \mathrm{OD}\right): \delta 2.00\left(\mathrm{~s}, 3 \mathrm{H}, \mathrm{CH}_{3}\right), 2.95(\mathrm{t}, 2 \mathrm{H}, J=7.8$ $\left.\mathrm{Hz}, \mathrm{CH}_{2}\right), 3.20\left(\mathrm{t}, 2 \mathrm{H}, J=7.8 \mathrm{~Hz}, \mathrm{CH}_{2}\right), 7.07(\mathrm{~s}, 2 \mathrm{H}, \mathrm{Ar}), 7.30(\mathrm{~d}, 2 \mathrm{H}$, $J=8.4 \mathrm{~Hz}, \mathrm{Ar}), 7.53(\mathrm{~d}, 2 \mathrm{H}, J=8.4 \mathrm{~Hz}, \mathrm{Ar}) \mathrm{ppm} .{ }^{13} \mathrm{C}$ NMR $\left(\mathrm{CD}_{3} \mathrm{OD}\right): \delta 143.35,140.41,137.50,137.27,132.17,130.72,128.97$, 124.52, 41.98, 34.21, 20.84 ppm. Anal. $\left(\mathrm{C}_{16} \mathrm{H}_{20} \mathrm{~N}_{2} \cdot \mathrm{HCl}\right) \mathrm{C}, \mathrm{H}, \mathrm{N} . \%$ Calcd: $79.96(\mathrm{C}) ; 8.39(\mathrm{H}) ; 11.66(\mathrm{~N})$. \% Found: $79.90(\mathrm{C}) ; 8.49$ $(\mathrm{H}) ; 11.71(\mathrm{~N})$.

4-(4-(2-Aminoethoxy)-2,6-dimethylbenzyl)aniline (7). Compound 7 was synthesized from $33(186.2 \mathrm{mg}, 0.66 \mathrm{mmol}), \mathrm{LiAlH}_{4}(6.87 \mathrm{~mL}$, $6.87 \mathrm{mmol})$, and $\mathrm{AlCl}_{3}(915.6 \mathrm{mg}, 6.87 \mathrm{mmol})$ in THF $(25 \mathrm{~mL})$ following the same procedure described above for the preparation of 1 . The crude was purified by conversion to the corresponding hydrochloride salt. White solid; mp $156-158{ }^{\circ} \mathrm{C}$ (75\% yield). ${ }^{1} \mathrm{H}$
$\operatorname{NMR}\left(\mathrm{CD}_{3} \mathrm{OD}\right): \delta 2.20\left(\mathrm{~s}, 6 \mathrm{H}, \mathrm{CH}_{3}\right), 3.37\left(\mathrm{t}, 2 \mathrm{H}, J=5.0 \mathrm{~Hz}, \mathrm{CH}_{3}\right)$, $4.07\left(\mathrm{~s}, 2 \mathrm{H}, \mathrm{CH}_{2}\right), 4.23\left(\mathrm{t}, 2 \mathrm{H}, J=5.0 \mathrm{~Hz}, \mathrm{CH}_{2}\right), 6.76(\mathrm{~s}, 2 \mathrm{H}, \mathrm{Ar}), 7.15$ (d, $2 \mathrm{H}, J=8.4 \mathrm{~Hz}, \mathrm{Ar}), 7.30(\mathrm{~d}, 2 \mathrm{H}, J=8.4 \mathrm{~Hz}, \mathrm{Ar}) \mathrm{ppm} .{ }^{13} \mathrm{C} \mathrm{NMR}$ (CD $\left.{ }_{3} \mathrm{OD}\right): \delta 156.50,141.82,138.32,129.24,129.09,128.16,122.72$, 114.04, 63.74, 39.07, 33.21, 19.10 ppm. Anal. $\left(\mathrm{C}_{17} \mathrm{H}_{22} \mathrm{~N}_{2} \mathrm{O} \cdot \mathrm{HCl}\right) \mathrm{C}, \mathrm{H}$, N. \% Calcd: $75.52(\mathrm{C}) ; 8.20(\mathrm{H}) ; 10.36(\mathrm{~N})$. \% Found: $75.60(\mathrm{C})$; $8.07(\mathrm{H}) ; 10.40(\mathrm{~N})$.

4-(4-(2-Aminoethyl)-2-methylbenzyl)-N-ethyl-2-isopropylaniline (8). Compound 8 was synthesized from $37(130.8 \mathrm{mg}, 0.41 \mathrm{mmol})$, $\mathrm{LiAlH}_{4}(1.84 \mathrm{~mL}, 1.84 \mathrm{mmol})$, and $\mathrm{AlCl}_{3}(244.8 \mathrm{mg}, 1.84 \mathrm{mmol})$ in THF $(17 \mathrm{~mL})$ following the same procedure described above for the preparation of 1 . The crude was purified by conversion in the corresponding hydrochloride salt. Brown solid; mp $148-150{ }^{\circ} \mathrm{C}(67 \%$ yield). ${ }^{1} \mathrm{H}$ NMR $\left(\mathrm{CD}_{3} \mathrm{OD}\right): \delta 1.28\left(\mathrm{~d}, 6 \mathrm{H}, J=6.8 \mathrm{~Hz}, \mathrm{CH}_{3}\right), 1.37(\mathrm{t}$, $\left.3 \mathrm{H}, J=7.2 \mathrm{~Hz}, \mathrm{CH}_{3}\right), 2.22\left(\mathrm{~s}, 3 \mathrm{H}, \mathrm{CH}_{3}\right), 2.93(\mathrm{t}, 2 \mathrm{H}, J=7.8 \mathrm{~Hz}$, $\left.\mathrm{CH}_{2}\right), 3.05-3.12(\mathrm{~m}, 1 \mathrm{H}, \mathrm{CH}), 3.16\left(\mathrm{t}, 2 \mathrm{H}, J=7.8 \mathrm{~Hz}, \mathrm{CH}_{2}\right), 3.43(\mathrm{q}$, $\left.2 \mathrm{H}, J=7.2 \mathrm{~Hz}, \mathrm{CH}_{2}\right), 4.04\left(\mathrm{~s}, 2 \mathrm{H}, \mathrm{CH}_{2}\right), 7.06-7.14(\mathrm{~m}, 4 \mathrm{H}, \mathrm{Ar}), 7.32$ $(\mathrm{d}, 1 \mathrm{H}, J=8.4 \mathrm{~Hz}, \mathrm{Ar}), 7.36(\mathrm{~d}, 1 \mathrm{H}, J=1.6 \mathrm{~Hz}, \mathrm{Ar}) \mathrm{ppm} .{ }^{13} \mathrm{C}$ NMR $\left(\mathrm{CD}_{3} \mathrm{OD}\right): \delta 144.42,143.51,138.47,138.36,136.41,131.87,131.56$, $131.00,129.52,128.88,127.54,124.53,49.90,41.97,39.45,34.11$, 28.70, 24.43, 19.72, 11.38 ppm. Anal. $\left(\mathrm{C}_{21} \mathrm{H}_{30} \mathrm{~N}_{2} \cdot \mathrm{HCl}\right) \mathrm{C}, \mathrm{H}, \mathrm{N} . \%$ Calcd: $81.24(\mathrm{C}) ; 9.74(\mathrm{H}) ; 9.02(\mathrm{~N})$. \% Found: $81.36(\mathrm{C}) ; 9.65(\mathrm{H})$; $9.11(\mathrm{~N})$.

$\mathrm{N}$-(4-(4-(2-Aminoethyl)-2-methylbenzyl)-2-isopropylphenyl)- $\mathrm{N}$ ethylacetamide (9). Compound 9 was synthesized from $8(45.6 \mathrm{mg}$, $0.15 \mathrm{mmol})$, saturated $\mathrm{NaHCO}_{3}$ solution $(0.05 \mathrm{~mL})$, and $\mathrm{Ac}_{2} \mathrm{O}(0.01$ $\mathrm{mL}, 0.15 \mathrm{mmol}$ ) following the same procedure described above for the preparation of 3. The crude solid was collected by filtration and purified by conversion to the corresponding hydrochloride salt. Yellow solid (30\% yield). ${ }^{1} \mathrm{H}$ NMR $\left(\mathrm{CD}_{3} \mathrm{OD}\right): \delta 1.08-1.20\left(\mathrm{~m}, 9 \mathrm{H}, \mathrm{CH}_{3}\right.$, $\left.\mathrm{CH}_{3} \mathrm{CH}_{2}\right), 1.73\left(\mathrm{~s}, 3 \mathrm{H}, \mathrm{COCH}_{3}\right), 2.24\left(\mathrm{~s}, 3 \mathrm{H}, \mathrm{CH}_{3}\right), 2.90-2.96(\mathrm{~m}$, $\left.3 \mathrm{H}, \mathrm{CH}_{2}, \mathrm{CH}\right), 3.02-3.07\left(\mathrm{~m}, 1 \mathrm{H}, \mathrm{CH}_{2}\right), 3.17(\mathrm{t}, 2 \mathrm{H}, J=7.4 \mathrm{~Hz}$, $\left.\mathrm{CH}_{2}\right), 4.02\left(\mathrm{~s}, 2 \mathrm{H}, \mathrm{CH}_{2}\right), 4.11-4.18\left(\mathrm{~m}, 1 \mathrm{H}, \mathrm{CH}_{2}\right), 6.97-7.05(\mathrm{~m}$, $2 \mathrm{H}, \mathrm{Ar}$ ), 7.07-7.17 (m, 3H, Ar), 7.27 (s, 1H, Ar) ppm. ${ }^{13} \mathrm{C}$ NMR $\left(\mathrm{CD}_{3} \mathrm{OD}\right): \delta 173.03,146.93,143.12,138.91,138.71,138.36,136.21$, $131.81,131.53,130.08,128.87,128.30,127.47,45.29,42.01,39.67$, $34.10,28.83,24.48,24.13,22.59,19.77,12.99$ ppm. Anal. $\left(\mathrm{C}_{23} \mathrm{H}_{32} \mathrm{~N}_{2} \mathrm{O} \cdot \mathrm{HCl}\right)$ C, H, N. \% Calcd: $78.36(\mathrm{C}) ; 9.15(\mathrm{H}) ; 7.95$ (N). \% Found: $78.45(\mathrm{C}) ; 9.02(\mathrm{H}) ; 7.84(\mathrm{~N})$.

$\mathrm{N}$-(4-(4-(2-Acetamidoethyl)-2-methylbenzyl)-2-isopropylphenyl)$\mathrm{N}$-ethylacetamide (10). Compound 10 was synthesized from 8 (45.6 $\mathrm{mg}, 0.15 \mathrm{mmol})$, saturated $\mathrm{NaHCO}_{3}$ solution $(0.05 \mathrm{~mL})$, and $\mathrm{Ac}_{2} \mathrm{O}$ $(0.02 \mathrm{~mL}, 0.30 \mathrm{mmol})$ following the same procedure described above for the preparation of 3 . The reaction mixture was evaporated and the crude dissolved in AcOEt and washed twice with water. The evaporation of the organic collected phases gave final product as a white oil (20\% yield). ${ }^{1} \mathrm{H}$ NMR ( $\left.\mathrm{CD}_{3} \mathrm{OD}\right): \delta 1.10-1.20\left(\mathrm{~m}, 9 \mathrm{H}, \mathrm{CH}_{3}\right.$, $\left.\mathrm{CH}_{3} \mathrm{CH}_{2}\right), 1.73\left(\mathrm{~s}, 3 \mathrm{H}, \mathrm{COCH}_{3}\right), 1.90\left(\mathrm{~s}, 3 \mathrm{H}, \mathrm{COCH}_{3}\right), 2.21(\mathrm{~s}, 3 \mathrm{H}$, $\left.\mathrm{CH}_{3}\right), 2.74\left(\mathrm{t}, 2 \mathrm{H}, \mathrm{J}=7.4 \mathrm{~Hz}, \mathrm{CH}_{2}\right), 2.90-2.96(\mathrm{~m}, 1 \mathrm{H}, \mathrm{CH}), 3.01-$ $3.09\left(\mathrm{~m}, 1 \mathrm{H}, \mathrm{CH}_{2}\right), 3.37\left(\mathrm{t}, 2 \mathrm{H}, J=7.4 \mathrm{~Hz}, \mathrm{CH}_{2}\right), 4.00\left(\mathrm{~s}, 2 \mathrm{H}, \mathrm{CH}_{2}\right)$, 4.11-4.20 (m, 1H, $\left.\mathrm{CH}_{2}\right), 6.99-7.09(\mathrm{~m}, 5 \mathrm{H}, \mathrm{Ar}), 7.25$ (d, $1 \mathrm{H}, J=1.2$ $\mathrm{Hz}, \mathrm{Ar}) \mathrm{ppm} .{ }^{13} \mathrm{C}$ NMR $\left(\mathrm{CD}_{3} \mathrm{OD}\right): \delta 173.20,173.08,146.89,143.36$, 138.82 , 138.68, 137.88, 137.74, 131.86, 131.13, 130.06, 128.84, 128.28, $127.48,45.34,42.13,39.71,36.09,28.86,24.50,24.16,22.60,22.52$, 19.78, 13.00 ppm. Anal. $\left(\mathrm{C}_{25} \mathrm{H}_{34} \mathrm{~N}_{2} \mathrm{O}_{2}\right)$ C, H, N. \% Calcd: 76.10 (C); $8.69(\mathrm{H}) ; 7.10(\mathrm{~N})$. \% Found: $76.25(\mathrm{C}) ; 8.53(\mathrm{H}) ; 7.21(\mathrm{~N})$.

$\mathrm{N}$-(4-(4-(2-Aminoethoxy)benzyl)phenyl)acetamide (11). Compound 11 was synthesized from SG1 ${ }^{4}(49.7 \mathrm{mg}, 0.20 \mathrm{mmol})$, saturated $\mathrm{NaHCO}_{3}$ solution $(0.07 \mathrm{~mL})$, and $\mathrm{Ac}_{2} \mathrm{O}(0.03 \mathrm{~mL}, 0.20$ $\mathrm{mmol}$ ) following the same procedure described above for the preparation of 3. The crude product was purified by precipitation from $\mathrm{MeOH} / \mathrm{Et}_{2} \mathrm{O}$ to give 11. White solid; $\mathrm{mp} 132-136{ }^{\circ} \mathrm{C}(60 \%$ yield). ${ }^{1} \mathrm{H}$ NMR ( $\left.\mathrm{CD}_{3} \mathrm{OD}\right): \delta 2.10\left(\mathrm{~s}, 3 \mathrm{H}, \mathrm{COCH}_{3}\right), 3.34(\mathrm{t}, 2 \mathrm{H}, J=$ $\left.5.2 \mathrm{~Hz}, \mathrm{CH}_{2}\right), 3.87\left(\mathrm{~s}, 2 \mathrm{H}, \mathrm{CH}_{2}\right), 4.19\left(\mathrm{t}, 2 \mathrm{H}, J=5.2 \mathrm{~Hz}, \mathrm{CH}_{2}\right), 6.92$ $(\mathrm{d}, 2 \mathrm{H}, J=8.8 \mathrm{~Hz}, \mathrm{Ar}), 7.10-7.14(\mathrm{~m}, 4 \mathrm{H}, \mathrm{Ar}), 7.42(\mathrm{~d}, 2 \mathrm{H}, J=8.4$ $\mathrm{Hz}, \mathrm{Ar}) \mathrm{ppm} .{ }^{13} \mathrm{C}$ NMR $\left(\mathrm{CD}_{3} \mathrm{OD}\right): \delta 171.59,157.83,138.90,137.82$, $136.02,130.93,130.03,121.40,115.70,65.29,41.30,40.39,23.76$ ppm. Anal. $\left(\mathrm{C}_{17} \mathrm{H}_{20} \mathrm{~N}_{2} \cdot \mathrm{HCl}\right) \mathrm{C}, \mathrm{H}, \mathrm{N}$. \% Calcd: $71.81(\mathrm{C}) ; 7.09(\mathrm{H}) ; 9.85$ (N). \% Found: $71.88(\mathrm{C}) ; 7.15(\mathrm{H}) ; 9.92(\mathrm{~N})$. 
$N$-(2-(4-(4-Acetamidobenzyl)phenoxy)ethyl)acetamide (12). Compound 12 was synthesized from SG1 $(47.0 \mathrm{mg}, 0.19 \mathrm{mmol})$, saturated $\mathrm{NaHCO}_{3}$ solution $(0.14 \mathrm{~mL})$, and $\mathrm{Ac}_{2} \mathrm{O}(0.04 \mathrm{~mL}, 0.38$ mmol) following the same procedure described above for the preparation of 3 . The crude product was purified by precipitation from $\mathrm{MeOH}$ /acetone to give 12 . White solid; $\mathrm{mp} 152-153{ }^{\circ} \mathrm{C}(60 \%$ yield). ${ }^{1} \mathrm{H}$ NMR (DMSO): $\delta 2.00\left(\mathrm{~s}, 3 \mathrm{H}, \mathrm{COCH}_{3}\right), 2.08(\mathrm{~s}, 3 \mathrm{H}$, $\left.\mathrm{COCH}_{3}\right), 3.34-3.38\left(\mathrm{~m}, 2 \mathrm{H}, \mathrm{CH}_{2}\right), 3.79\left(\mathrm{~s}, 2 \mathrm{H}, \mathrm{CH}_{2}\right), 3.91(\mathrm{t}, 2 \mathrm{H}, J$ $\left.=5.6 \mathrm{~Hz}, \mathrm{CH}_{2}\right), 6.84(\mathrm{~d}, 2 \mathrm{H}, J=8.8 \mathrm{~Hz}, \mathrm{Ar}), 7.08-7.10(\mathrm{~m}, 4 \mathrm{H}, \mathrm{Ar})$, $7.45(\mathrm{~d}, 2 \mathrm{H}, J=8.8 \mathrm{~Hz}, \mathrm{Ar}), 8.06\left(\mathrm{br} \mathrm{t}, \mathrm{NH}_{2}\right), 9.83$ (br s, NH) ppm. ${ }^{13} \mathrm{C}$ NMR ( $\left.\mathrm{CD}_{3} \mathrm{OD}\right): \delta 173.59,171.54,158.58,139.08,137.78,135.20$, 130.82, 130.06, 121.39, 115.59, 67.53, 41.32, 40.26, 23.70, 22.46 ppm.. Anal. $\left(\mathrm{C}_{19} \mathrm{H}_{22} \mathrm{~N}_{2} \mathrm{O}_{3} \cdot \mathrm{HCl}\right) \mathrm{C}, \mathrm{H}, \mathrm{N} . \%$ Calcd: $69.92(\mathrm{C}) ; 6.79(\mathrm{H}) ; 8.58$ $(\mathrm{N})$. \% Found: $69.88(\mathrm{C}) ; 6.67(\mathrm{H}) ; 8.61(\mathrm{~N})$.

$\mathrm{N}$-(4-(4-(2-Aminoethoxy)-2-methylbenzyl)phenyl)acetamide (13). Compound 13 was synthesized from SG2 ${ }^{4}(50.0 \mathrm{mg}, 0.19 \mathrm{mmol})$, saturated $\mathrm{NaHCO}_{3}$ solution $(0.07 \mathrm{~mL})$, and $\mathrm{Ac}_{2} \mathrm{O}(0.02 \mathrm{~mL}, 0.19$ $\mathrm{mmol}$ ) following the same procedure described above for the preparation of 3 . The crude product was purified by precipitation from $\mathrm{MeOH} / \mathrm{Et}_{2} \mathrm{O}$ to give 13. White solid; $\mathrm{mp} 132-136{ }^{\circ} \mathrm{C}(60 \%$ yield). ${ }^{1} \mathrm{H}$ NMR $\left(\mathrm{CD}_{3} \mathrm{OD}\right): \delta 2.10\left(\mathrm{~s}, 3 \mathrm{H}, \mathrm{CH}_{3}\right), 2.19(\mathrm{~s}, 3 \mathrm{H}$, $\left.\mathrm{COCH}_{3}\right), 3.34\left(\mathrm{t}, 2 \mathrm{H}, J=5.0 \mathrm{~Hz}, \mathrm{CH}_{2}\right), 3.89\left(\mathrm{~s}, 2 \mathrm{H}, \mathrm{CH}_{2}\right), 4.20(\mathrm{t}$, $\left.2 \mathrm{H}, J=5.0 \mathrm{~Hz}, \mathrm{CH}_{2}\right), 6.77$ (dd, $\left.1 \mathrm{H}, J=2.4,8.4 \mathrm{~Hz}, \mathrm{Ar}\right), 6.83(\mathrm{~d}, 1 \mathrm{H}, J$ $=2.4 \mathrm{~Hz}, \mathrm{Ar}), 7.03(\mathrm{~d}, 2 \mathrm{H}, J=8.4 \mathrm{~Hz}, \mathrm{Ar}), 7.06(\mathrm{~d}, 1 \mathrm{H}, J=8.4 \mathrm{~Hz}$, Ar), 7.41 (d, $2 \mathrm{H}, J=8.4 \mathrm{~Hz}, \mathrm{Ar}) \mathrm{ppm} .{ }^{13} \mathrm{C} \mathrm{NMR}\left(\mathrm{CD}_{3} \mathrm{OD}\right): \delta 171.58$, $158.00,139.19,138.03,137.67,133.61,132.00,129.79,121.32,117.73$, 112.83, 65.18, 40.41, 38.93, 23.79, 19.96 ppm. Anal. $\left(\mathrm{C}_{18} \mathrm{H}_{22} \mathrm{~N}_{2} \mathrm{O}_{2}\right.$. HCl) C, H, N. \% Calcd: $72.46(\mathrm{C}) ; 7.43(\mathrm{H}) ; 9.39(\mathrm{~N}) . \%$ Found: $72.58(\mathrm{C}) ; 7.55(\mathrm{H}) ; 9.42(\mathrm{~N})$.

$\mathrm{N}$-(2-(4-(4-Acetamidobenzyl)-3-methylphenoxy)ethyl)acetamide (14). Compound 14 was synthesized from SG2 $(50.0 \mathrm{mg}, 0.19 \mathrm{mmol})$, saturated $\mathrm{NaHCO}_{3}$ solution $(0.14 \mathrm{~mL})$, and $\mathrm{Ac}_{2} \mathrm{O}(0.04 \mathrm{~mL}, 0.38$ $\mathrm{mmol}$ ) following the same procedure described above for the preparation of 3 . The crude product was purified by precipitation from $\mathrm{MeOH} / \mathrm{Et}_{2} \mathrm{O}$ to give 14. White solid; mp $139-141{ }^{\circ} \mathrm{C}(56 \%$ yield). ${ }^{1} \mathrm{H}$ NMR $\left(\mathrm{CD}_{3} \mathrm{OD}\right): \delta 1.95\left(\mathrm{~s}, 3 \mathrm{H}, \mathrm{CH}_{3}\right), 2.09(\mathrm{~s}, 3 \mathrm{H}$, $\left.\mathrm{COCH}_{3}\right), 2.16\left(\mathrm{~s}, 3 \mathrm{H}, \mathrm{COCH}_{3}\right), 3.53\left(\mathrm{t}, 2 \mathrm{H}, J=5.6 \mathrm{~Hz}, \mathrm{CH}_{2}\right), 3.87$ $\left(\mathrm{s}, 2 \mathrm{H}, \mathrm{CH}_{2}\right), 4.00\left(\mathrm{t}, 2 \mathrm{H}, J=5.6 \mathrm{~Hz}, \mathrm{CH}_{2}\right), 6.70(\mathrm{dd}, 1 \mathrm{H}, J=2.4,8.4$ $\mathrm{Hz}, \mathrm{Ar}), 6.74(\mathrm{~d}, 1 \mathrm{H}, J=2.4 \mathrm{~Hz}, \mathrm{Ar}), 6.99-7.03(\mathrm{~m}, 3 \mathrm{H}, \mathrm{Ar}), 7.41$ (d, $2 \mathrm{H}, J=8.4 \mathrm{~Hz}, \mathrm{Ar}) \mathrm{ppm} .{ }^{13} \mathrm{C} \mathrm{NMR}\left(\mathrm{CD}_{3} \mathrm{OD}\right): \delta 173.60,171.53$, $158.78,139.01,138.27,137.66,132.85,131.94,129.83,121.32,117.66$, $112.72,67.42,40.30,38.98,23.70,22.47,19.96$ ppm. Anal. $\left(\mathrm{C}_{20} \mathrm{H}_{24} \mathrm{~N}_{2} \mathrm{O}_{3} \cdot \mathrm{HCl}\right)$ C, H, N. \% Calcd: $70.56(\mathrm{C}) ; 7.11(\mathrm{H}) ; 8.23$ (N). \% Found: $70.43(\mathrm{C}) ; 7.05(\mathrm{H}) ; 8.22(\mathrm{~N})$.

$\mathrm{N}$-(4-(4-(2-(3-Carbamimidoylguanidino)ethoxy)-2-methylbenzyl)phenyl)acetamide (15). A mixture of 13 (32.3 mg, 0.16 $\mathrm{mmol})$ and dicyandiamide $(13.5 \mathrm{mg}, 0.16 \mathrm{mmol})$ was heated to 160 ${ }^{\circ} \mathrm{C}$ for $100 \mathrm{~min}$. The reaction mixture initially melts, then resolidifies. The reaction was cooled to room temperature. The crude product was purified by crystallization from $\mathrm{EtOH} / \mathrm{Et}_{2} \mathrm{O}$. Brown oil ( $52 \%$ yield). ${ }^{1} \mathrm{H}$ NMR (CD $\left.3 \mathrm{OD}\right): \delta 2.09\left(\mathrm{~s}, 3 \mathrm{H}, \mathrm{CH}_{3}\right), 2.15\left(\mathrm{~s}, 3 \mathrm{H}, \mathrm{COCH}_{3}\right), 3.60$ $\left(\mathrm{t}, 2 \mathrm{H}, J=5.2 \mathrm{~Hz}, \mathrm{CH}_{2}\right), 3.86\left(\mathrm{~s}, 2 \mathrm{H}, \mathrm{CH}_{2}\right), 4.05(\mathrm{t}, 2 \mathrm{H}, J=5.2 \mathrm{~Hz}$, $\left.\mathrm{CH}_{2}\right), 6.65-6.77(\mathrm{~m}, 3 \mathrm{H}, \mathrm{Ar}), 7.01(\mathrm{~d}, 2 \mathrm{H}, J=8.0 \mathrm{~Hz}, \mathrm{Ar}), 7.41(\mathrm{~d}$, $2 \mathrm{H}, J=8.0 \mathrm{~Hz}, \mathrm{Ar}) \mathrm{ppm} .{ }^{13} \mathrm{C} \mathrm{NMR}\left(\mathrm{CD}_{3} \mathrm{OD}\right): \delta 171.60,162.12$, $161.01,158.56,139.04,138.20,137.63,133.00,131.94,129.80,121.34$, $117.63,112.73,67.55,42.15,38.94,23.74,19.97$ ppm. Anal. $\left(\mathrm{C}_{20} \mathrm{H}_{26} \mathrm{~N}_{6} \mathrm{O}_{2}\right)$ C, H, N. \% Calcd: $62.81(\mathrm{C}) ; 6.85(\mathrm{H}) ; 21.97(\mathrm{~N})$. \% Found: $62.95(\mathrm{C}) ; 6.73(\mathrm{H}) ; 21.76(\mathrm{~N})$.

4-(4-(2-(3-Carbamimidoylguanidino)ethoxy)-2-methylbenzyl)aniline (16). To a solution of the amide $15(0.57 \mathrm{mmol})$ in $\mathrm{MeOH}$ was added dropwise an aqueous solution of $\mathrm{HCl} 1 \mathrm{~N}(0.2 \mathrm{~mL})$; the resulting solution was refluxed for $2 \mathrm{~h}$, and then, after cooling, the solvent was evaporated. The residue was purified by precipitation from $\mathrm{EtOH} / \mathrm{Et}_{2} \mathrm{O}$. Brown oil (60\% yield). ${ }^{1} \mathrm{H}$ NMR ( $\left.\mathrm{CD}_{3} \mathrm{OD}\right): \delta 2.17$ (s, $\left.3 \mathrm{H}, \mathrm{CH}_{3}\right), 3.79\left(\mathrm{t}, 2 \mathrm{H}, J=4.8 \mathrm{~Hz}, \mathrm{CH}_{2}\right), 3.99\left(\mathrm{~s}, 2 \mathrm{H}, \mathrm{CH}_{2}\right), 4.21(\mathrm{t}$, $\left.2 \mathrm{H}, J=4.8 \mathrm{~Hz}, \mathrm{CH}_{2}\right), 6.79(\mathrm{dd}, 1 \mathrm{H}, J=2.6,8.2, \mathrm{Ar}), 6.83(\mathrm{~d}, 1 \mathrm{H}, J=$ $2.6 \mathrm{~Hz}, \mathrm{Ar}), 7.08(\mathrm{~d}, 1 \mathrm{H}, J=8.2 \mathrm{~Hz}, \mathrm{Ar}), 7.26(\mathrm{~d}, 2 \mathrm{H}, J=8.6 \mathrm{~Hz}, \mathrm{Ar})$, $7.32(\mathrm{~d}, 2 \mathrm{H}, J=8.6 \mathrm{~Hz}, \mathrm{Ar})$ ppm. Anal. $\left(\mathrm{C}_{18} \mathrm{H}_{24} \mathrm{~N}_{6} \mathrm{O}\right) \mathrm{C}, \mathrm{H}, \mathrm{N} . \%$ Calcd: $63.51(\mathrm{C}) ; 7.11(\mathrm{H}) ; 24.69(\mathrm{~N})$. \% Found: $63.72(\mathrm{C}) ; 7.05$ $(\mathrm{H}) ; 24.53(\mathrm{~N})$.
4-(Chloromethyl)-2-methyl-1-(4-nitrobenzyl)benzene (21). To a solution of alcohol $17(96.0 \mathrm{mg}, 0.35 \mathrm{mmol})$ in $\mathrm{CHCl}_{3}$ at $0{ }^{\circ} \mathrm{C}$ was added $\mathrm{SOCl}_{2}(3.50 \mathrm{mmol}, 0.25 \mathrm{~mL})$. The reaction mixture was stirred for $2 \mathrm{~h}$ at room temperature, and then the solvent was evaporated. The residue was dissolved in $\mathrm{H}_{2} \mathrm{O}$ and alkalized with $\mathrm{NaOH} 1 \mathrm{~N}$, and the aqueous layer was extracted with DCM. The organic phase was dried, and the solvent was evaporated to give the corresponding crude 21, which was used without further purification. Yellow oil (80\% yield). ${ }^{1} \mathrm{H} \mathrm{NMR}\left(\mathrm{CDCl}_{3}\right): \delta 2.22\left(\mathrm{~s}, 3 \mathrm{H}, \mathrm{CH}_{3}\right), 4.08\left(\mathrm{~s}, 2 \mathrm{H}, \mathrm{CH}_{2}\right), 4.57(\mathrm{~s}$, $\left.2 \mathrm{H}, \mathrm{CH}_{2}\right), 7.09$ (d, $\left.1 \mathrm{H}, J=7.6 \mathrm{~Hz}, \mathrm{Ar}\right), 7.19-7.24$ (m, 2H, Ar), 7.26 (d, $2 \mathrm{H}, J=7.4 \mathrm{~Hz}, \mathrm{Ar}), 8.13$ (d, $2 \mathrm{H}, J=7.4 \mathrm{~Hz}, \mathrm{Ar}$ ) ppm. Anal. $\left(\mathrm{C}_{15} \mathrm{H}_{14} \mathrm{ClNO}_{2}\right)$ C, H, N. \% Calcd: $65.34(\mathrm{C}) ; 5.12(\mathrm{H}) ; 5.08(\mathrm{~N}) . \%$ Found: $65.52(\mathrm{C}) ; 5.03(\mathrm{H}) ; 5.24(\mathrm{~N})$.

5-(Chloromethyl)-1,3-dimethyl-2-(4-nitrobenzyl)benzene (22). Compound 22 was synthesized from $18(224 \mathrm{mg}, 0.87 \mathrm{mmol})$ and $\mathrm{SOCl}_{2}(0.63 \mathrm{~mL}, 8.70 \mathrm{mmol})$ in $\mathrm{CHCl}_{3}(25 \mathrm{~mL})$ following the same procedure described above for the preparation of 21 . The crude was used without further purification. White oil (76\% yield). ${ }^{1} \mathrm{H}$ NMR $\left(\mathrm{CDCl}_{3}\right): \delta 2.22\left(\mathrm{~s}, 6 \mathrm{H}, \mathrm{CH}_{3}\right), 4.14\left(\mathrm{~s}, 2 \mathrm{H}, \mathrm{CH}_{2}\right), 4.56\left(\mathrm{~s}, 2 \mathrm{H}, \mathrm{CH}_{2}\right)$, 7.13 (s, 2H, Ar), 7.15 (d, 2H, J = 8.5 Hz Ar), $8.11(\mathrm{~d}, 2 \mathrm{H}, J=8.5 \mathrm{~Hz}$ Ar) ppm. Anal. $\left(\mathrm{C}_{16} \mathrm{H}_{16} \mathrm{ClNO}_{2}\right)$ C, H, N. \% Calcd: 66.32 (C); 5.57 $(\mathrm{H}) ; 4.83(\mathrm{~N})$. \% Found: $66.49(\mathrm{C}) ; 5.59(\mathrm{H}) ; 5.11(\mathrm{~N})$.

4-(Chloromethyl)-2-methyl-4'-nitro-1,1'-biphenyl (23). Compound 23 was synthesized from $19(125 \mathrm{mg}, 0.51 \mathrm{mmol})$ and $\mathrm{SOCl}_{2}(0.37 \mathrm{~mL}, 5.10 \mathrm{mmol})$ in $\mathrm{CHCl}_{3}(25 \mathrm{~mL})$ following the same procedure described above for the preparation of 21. The crude was used without further purification. Yellow oil (83\% yield). ${ }^{1} \mathrm{H}$ NMR $\left(\mathrm{CDCl}_{3}\right): \delta 2.27\left(\mathrm{~s}, 3 \mathrm{H}, \mathrm{CH}_{3}\right), 4.61\left(\mathrm{~s}, 2 \mathrm{H}, \mathrm{CH}_{2}\right), 7.21(\mathrm{~d}, 2 \mathrm{H}, J=7.8$ $\mathrm{Hz}, \mathrm{Ar}), 7.31$ (d, 1H, $J=7.8 \mathrm{~Hz}, \mathrm{Ar}), 7.34$ (s, $1 \mathrm{H}, \mathrm{Ar}), 7.48$ (d, 2H, $J=$ $8.8 \mathrm{~Hz}, \mathrm{Ar}), 8.29(\mathrm{~d}, 2 \mathrm{H}, J=8.8 \mathrm{~Hz} \mathrm{Ar})$ ppm. Anal. $\left(\mathrm{C}_{14} \mathrm{H}_{12} \mathrm{ClNO}_{2}\right) \mathrm{C}$, H, N. \% Calcd: $64.25(\mathrm{C})$; $4.62(\mathrm{H})$; $5.35(\mathrm{~N})$. \% Found: 63.91 (C); $4.68(\mathrm{H}) ; 5.40(\mathrm{~N})$.

4-(Chloromethyl)-2,6-dimethyl-4'-nitro-1,1'-biphenyl (24). Compound 24 was synthesized from $20(134 \mathrm{mg}, 0.52 \mathrm{mmol})$ and $\mathrm{SOCl}_{2}$ $(0.38 \mathrm{~mL}, 5.20 \mathrm{mmol})$ in $\mathrm{CHCl}_{3}(25 \mathrm{~mL})$ following the same procedure described above for the preparation of 21 . The crude was used without further purification. White oil (81\% yield). ${ }^{1} \mathrm{H}$ NMR $\left(\mathrm{CDCl}_{3}\right): \delta 2.02\left(\mathrm{~s}, 6 \mathrm{H}, \mathrm{CH}_{3}\right), 4.58\left(\mathrm{~s}, 2 \mathrm{H}, \mathrm{CH}_{2}\right), 7.17(\mathrm{~s}, 2 \mathrm{H}, \mathrm{Ar})$, $7.33(\mathrm{~d}, 2 \mathrm{H}, J=8.8 \mathrm{~Hz} \mathrm{Ar}), 8.31(\mathrm{~d}, 2 \mathrm{H}, J=8.8 \mathrm{~Hz} \mathrm{Ar}) \mathrm{ppm}$. Anal. $\left(\mathrm{C}_{15} \mathrm{H}_{14} \mathrm{ClNO}_{2}\right)$ C, H, N. \% Calcd: $65.34(\mathrm{C}) ; 5.12(\mathrm{H}) ; 5.08(\mathrm{~N}) . \%$ Found: $65.40(\mathrm{C}) ; 5.59(\mathrm{H}) ; 5.31(\mathrm{~N})$.

2-(4-(4-Aminobenzyl)-3-methylphenyl)acetonitrile (25). To a solution of chloro compound $21(78.0 \mathrm{mg}, 0.46 \mathrm{mmol})$ in $\mathrm{CH}_{3} \mathrm{CN}$ $(0.62 \mathrm{~mL})$ was added $\mathrm{NaCN}(45.1 \mathrm{mg}, 0.92 \mathrm{mmol})$ in $\mathrm{H}_{2} \mathrm{O}(0.21$ $\mathrm{mL}$ ). The mixture was submitted to microwave irradiation (150W, 100 ${ }^{\circ} \mathrm{C}, 20 \mathrm{~min}$ ). After cooling, the solution was extracted with DCM. The organic phase was dried and evaporated to dryness. Yellow oil $(86 \%$ yield). ${ }^{1} \mathrm{H}$ NMR $\left(\mathrm{CDCl}_{3}\right): \delta 2.22\left(\mathrm{~s}, 3 \mathrm{H}, \mathrm{CH}_{3}\right), 3.71\left(\mathrm{~s}, 2 \mathrm{H}, \mathrm{CH}_{2}\right)$, $4.07\left(\mathrm{~s}, 2 \mathrm{H}, \mathrm{CH}_{2}\right), 7.09-7.18(\mathrm{~m}, 3 \mathrm{H}, \mathrm{Ar}), 7.25(\mathrm{~d}, 2 \mathrm{H}, J=8.6 \mathrm{~Hz}$, $\mathrm{Ar}), 8.13(\mathrm{~d}, 2 \mathrm{H}, J=8.6 \mathrm{~Hz}, \mathrm{Ar})$ ppm. Anal. $\left(\mathrm{C}_{16} \mathrm{H}_{14} \mathrm{~N}_{2} \mathrm{O}_{2}\right) \mathrm{C}, \mathrm{H}, \mathrm{N} . \%$ Calcd: $72.16(\mathrm{C}) ; 5.30(\mathrm{H}) ; 10.52(\mathrm{~N})$. \% Found: $72.34(\mathrm{C}) ; 5.02$ $(\mathrm{H}) ; 10.65(\mathrm{~N})$.

2-(3,5-Dimethyl-4-(4-nitrobenzyl)phenyl)acetonitrile (26). Compound 26 was synthesized from $22(193 \mathrm{mg}, 0.70 \mathrm{mmol})$ and $\mathrm{NaCN}$ (68.5 mg, $1.40 \mathrm{mmol})$ in $\mathrm{CH}_{3} \mathrm{CN} / \mathrm{H}_{2} \mathrm{O}(0.94 \mathrm{~mL} / 0.32 \mathrm{~mL})$ following the same procedure described above for the preparation of 25. The crude was used without further purification. White oil $\left(70 \%\right.$ yield). ${ }^{1} \mathrm{H}$ $\operatorname{NMR}\left(\mathrm{CDCl}_{3}\right): \delta 2.22\left(\mathrm{~s}, 6 \mathrm{H}, \mathrm{CH}_{3}\right), 3.70\left(\mathrm{~s}, 2 \mathrm{H}, \mathrm{CH}_{2}\right), 4.13(\mathrm{~s}, 2 \mathrm{H}$, $\left.\mathrm{CH}_{2}\right), 7.06(\mathrm{~s}, 2 \mathrm{H}, \mathrm{Ar}), 7.14(\mathrm{~d}, 2 \mathrm{H}, J=8.6 \mathrm{~Hz} \mathrm{Ar}), 8.11(\mathrm{~d}, 2 \mathrm{H}, J=$ $8.6 \mathrm{~Hz} \mathrm{Ar}) \mathrm{ppm}$. Anal. $\left(\mathrm{C}_{17} \mathrm{H}_{16} \mathrm{~N}_{2} \mathrm{O}_{2}\right) \mathrm{C}, \mathrm{H}, \mathrm{N} . \%$ Calcd: 72.84 (C); $5.75(\mathrm{H}) ; 9.99(\mathrm{~N})$. \% Found: $72.60(\mathrm{C}) ; 5.60(\mathrm{H}) ; 10.02(\mathrm{~N})$.

2-(2-Methyl-4'-nitro-[1,1'-biphenyl]-4-yl)acetonitrile (27). Compound 27 was synthesized from $23(95.0 \mathrm{mg}, 0.61 \mathrm{mmol})$ and $\mathrm{NaCN}$ (59.8 mg, $1.22 \mathrm{mmol})$ in $\mathrm{CH}_{3} \mathrm{CN} / \mathrm{H}_{2} \mathrm{O}(0.82 \mathrm{~mL} / 0.30 \mathrm{~mL})$ following the same procedure described above for the preparation of 25 . The crude was used without further purification. Yellow oil (86\% yield). ${ }^{1} \mathrm{H}$ $\operatorname{NMR}\left(\mathrm{CDCl}_{3}\right): \delta 2.28\left(\mathrm{~s}, 3 \mathrm{H}, \mathrm{CH}_{3}\right), 3.78\left(\mathrm{~s}, 2 \mathrm{H}, \mathrm{CH}_{2}\right), 7.21-7.31$ $(\mathrm{m}, 3 \mathrm{H}, \mathrm{Ar}), 7.47(\mathrm{~d}, 2 \mathrm{H}, J=7.0 \mathrm{~Hz}, \mathrm{Ar}), 8.29(\mathrm{~d}, 2 \mathrm{H}, J=7.0 \mathrm{~Hz} \mathrm{Ar})$ ppm. Anal. $\left(\mathrm{C}_{15} \mathrm{H}_{12} \mathrm{~N}_{2} \mathrm{O}_{2}\right)$ C, H, N. \% Calcd: $71.42(\mathrm{C}) ; 4.79(\mathrm{H})$; $11.10(\mathrm{~N})$. \% Found: $71.41(\mathrm{C}) ; 4.80(\mathrm{H}) ; 11.15(\mathrm{~N})$. 
2-(2,6-Dimethyl-4'-nitro-[1,1'-biphenyl]-4-yl)acetonitrile (28). Compound 28 was synthesized from $24(101 \mathrm{mg}, 0.36 \mathrm{mmol})$ and $\mathrm{NaCN}(35.3 \mathrm{mg}, 0.72 \mathrm{mmol})$ in $\mathrm{CH}_{3} \mathrm{CN} / \mathrm{H}_{2} \mathrm{O}(0.49 \mathrm{~mL} / 0.16 \mathrm{~mL})$ following the same procedure described above for the preparation of 25. The crude was used without further purification. Pale yellow oil (81\% yield). ${ }^{1} \mathrm{H}$ NMR $\left(\mathrm{CDCl}_{3}\right): \delta 2.02\left(\mathrm{~s}, 6 \mathrm{H}, \mathrm{CH}_{3}\right), 3.73(\mathrm{~s}, 2 \mathrm{H}$, $\mathrm{CH}_{2}$ ), 7.10 (s, 2H, Ar), 7.32 (d, $\left.2 \mathrm{H}, J=8.6 \mathrm{~Hz} \mathrm{Ar}\right), 8.31$ (d, $2 \mathrm{H}, J=$ $8.6 \mathrm{~Hz} \mathrm{Ar}) \mathrm{ppm}$. Anal. $\left(\mathrm{C}_{16} \mathrm{H}_{14} \mathrm{~N}_{2} \mathrm{O}_{2}\right)$ C, H, N. \% Calcd: $72.16(\mathrm{C})$; $5.30(\mathrm{H}) ; 10.52(\mathrm{~N})$. \% Found: $72.40(\mathrm{C}) ; 5.59(\mathrm{H}) ; 10.31(\mathrm{~N})$.

2-(4-(4-Aminobenzyl)-3-methylphenyl)acetonitrile (29). A solution of $25(136 \mathrm{mg}, 0.5 \mathrm{mmol})$ in $\mathrm{AcOH}(0.5 \mathrm{~mL})$ was hydrogenated in the presence of $10 \% \mathrm{Pd}-\mathrm{C}(28.3 \mathrm{mg})$, for $12 \mathrm{~h}$. Then the catalyst was filtered off, and the solvent was removed to dryness to give a crude product that was used in the subsequent step without any further purification. Yellow oil (80\% yield). ${ }^{1} \mathrm{H}$ NMR $\left(\mathrm{CDCl}_{3}\right) \delta: 2.24(\mathrm{~s}, 3 \mathrm{H}$, $\left.\mathrm{CH}_{3}\right), 3.68\left(\mathrm{~s}, 2 \mathrm{H}, \mathrm{CH}_{2}\right), 3.85\left(\mathrm{~s}, 2 \mathrm{H}, \mathrm{CH}_{2}\right), 6.61(\mathrm{~d}, 2 \mathrm{H}, J=8.4 \mathrm{~Hz}$, $\mathrm{Ar}), 6.88(\mathrm{~d}, 2 \mathrm{H}, J=8.4 \mathrm{~Hz}, \mathrm{Ar}), 7.06-7.12(\mathrm{~m}, 3 \mathrm{H}, \mathrm{Ar}) \mathrm{ppm}$. Anal. $\left(\mathrm{C}_{16} \mathrm{H}_{16} \mathrm{~N}_{2}\right)$ C, H, N. \% Calcd: $81.32(\mathrm{C})$; $6.82(\mathrm{H})$; $11.85(\mathrm{~N}) . \%$ Found: $81.45(\mathrm{C}) ; 6.73(\mathrm{H}) ; 11.98(\mathrm{~N})$.

2-(4-(4-Hydroxybenzyl)-3-methylphenyl)acetonitrile (30). To a mixture of aniline derivative $29(63.0 \mathrm{mg}, 0.26 \mathrm{mmol})$ in $\mathrm{H}_{2} \mathrm{O}$ was added dropwise with $\mathrm{H}_{2} \mathrm{SO}_{4 \text { conc }}(0.06 \mathrm{~mL})$, and the mixture was stirred at room temperature for $20 \mathrm{~min}$. Then a solution $\mathrm{NaNO}_{2}(17.9 \mathrm{mg}$, $0.26 \mathrm{mmol})$ in $\mathrm{H}_{2} \mathrm{O}(0.19 \mathrm{~mL})$ was added dropwise to the reaction mixture. The resulting solution was stirred for $1 \mathrm{~h}$ at $100{ }^{\circ} \mathrm{C}$. The mixture was cooled to room temperature, and the residue diluted with AcOEt and washed with brine. The collected organic layers were dried and evaporated to give compound $\mathbf{3 0}$ that was directly used in the next step. Yellow oil (60\% yield). ${ }^{1} \mathrm{H}$ NMR $\left(\mathrm{CDCl}_{3}\right) \delta: 2.22\left(\mathrm{~s}, 3 \mathrm{H}, \mathrm{CH}_{3}\right)$, $3.84\left(\mathrm{~s}, 2 \mathrm{H}, \mathrm{CH}_{2}\right), 4.06\left(\mathrm{~s}, 2 \mathrm{H}, \mathrm{CH}_{2}\right), 7.14-7.19$ (m, 3H, Ar), 7.277.33 (m, 4H, Ar) ppm. Anal. $\left(\mathrm{C}_{16} \mathrm{H}_{15} \mathrm{NO}\right) \mathrm{C}, \mathrm{H}, \mathrm{N} . \%$ Calcd: 80.98 (C); $6.37(\mathrm{H})$; $5.90(\mathrm{~N})$. \% Found: $80.72(\mathrm{C})$; $6.51(\mathrm{H})$; $5.84(\mathrm{~N})$.

5-Methoxy-1,3-dimethyl-2-(4-nitrobenzyl)benzene (31). To a solution of 4-methoxy-2,6-dimethylphenylboronic acid (473 mg, 2.63 $\mathrm{mmol})$ in acetone $/ \mathrm{H}_{2} \mathrm{O} 1: 1(4 \mathrm{~mL})$ was added, under nitrogen flux, $p$ nitrobenzyl bromide $(569 \mathrm{mg}, 2.63 \mathrm{mmol}), \mathrm{K}_{2} \mathrm{CO}_{3}(1.24 \mathrm{~g}$, 6.58 $\mathrm{mmol}$ ), and a catalytic amount of $\mathrm{PdCl}_{2}$. The resulting mixture was stirred at $\mathrm{rt}$ for $62 \mathrm{~h}$ in a sealed vial. The crude mixture was evaporated and then diluted with water and extracted with $\mathrm{Et}_{2} \mathrm{O}$. The organic phase was dried over sodium sulfate and concentrated under vacuum. The crude residue was purified by column chromatography petroleum ether/AcOEt (99:1), affording 31. Yellow oil. (49\% yield). ${ }^{1} \mathrm{H}$ NMR $\left(\mathrm{CDCl}_{3}\right): \delta 2.19\left(\mathrm{~s}, 6 \mathrm{H}, \mathrm{CH}_{3}\right), 3.80\left(\mathrm{~s}, 3 \mathrm{H}, \mathrm{OCH}_{3}\right), 4.08\left(\mathrm{~s}, 2 \mathrm{H}, \mathrm{CH}_{2}\right)$, $6.65(\mathrm{~s}, 2 \mathrm{H}, \mathrm{Ar}), 7.16(\mathrm{~d}, 2 \mathrm{H}, J=8.8 \mathrm{~Hz}, \mathrm{Ar}), 8.09(\mathrm{~d}, 2 \mathrm{H}, J=8.8 \mathrm{~Hz}$, Ar) ppm. Anal. $\left(\mathrm{C}_{16} \mathrm{H}_{17} \mathrm{NO}_{3}\right)$ C, H, N. \% Calcd: $70.83(\mathrm{C})$; $6.32(\mathrm{H})$; $5.16(\mathrm{~N})$. \% Found: $71.01(\mathrm{C}) ; 6.12(\mathrm{H}) ; 5.00(\mathrm{~N})$.

3,5-Dimethyl-4-(4-nitrobenzyl)phenol (32). A solution of 31 (0.39 $\mathrm{mmol})$ in anhydrous DCM $(1.5 \mathrm{~mL})$ was cooled to $-78{ }^{\circ} \mathrm{C}$ and treated dropwise with a solution of $\mathrm{BBr}_{3}$ in $\mathrm{DCM}(3.94 \mathrm{~mL}, 1.24$ $\mathrm{mmol}$ ); the resulting solution was stirred at the same temperature for 5 $\min$ and at $0{ }^{\circ} \mathrm{C}$ for $1 \mathrm{~h}$. The mixture was then diluted with water and extracted with DCM. Organic phase was dried and evaporated to give the product 32. Pale-yellow oil (64\% yield). ${ }^{1} \mathrm{H}$ NMR $\left(\mathrm{CDCl}_{3}\right): \delta 2.16$ $\left(\mathrm{s}, 6 \mathrm{H}, \mathrm{CH}_{3}\right), 4.06\left(\mathrm{~s}, 2 \mathrm{H}, \mathrm{CH}_{2}\right), 6.59(\mathrm{~s}, 2 \mathrm{H}, \mathrm{Ar}), 7.16(\mathrm{~d}, 2 \mathrm{H}, \mathrm{J}=8.8$ $\mathrm{Hz}, \mathrm{Ar}), 8.10(\mathrm{~d}, 2 \mathrm{H}, J=8.8 \mathrm{~Hz}, \mathrm{Ar}) \mathrm{ppm}$. Anal. $\left(\mathrm{C}_{15} \mathrm{H}_{15} \mathrm{NO}_{3}\right) \mathrm{C}, \mathrm{H}$, N. \% Calcd: $70.02(\mathrm{C}) ; 5.88(\mathrm{H}) ; 5.44(\mathrm{~N}) . \%$ Found: $70.00(\mathrm{C}) ; 5.91$ $(\mathrm{H}) ; 5.63(\mathrm{~N})$.

2-(3,5-Dimethyl-4-(4-nitrobenzyl)phenoxy)acetonitrile (33). To a mixture of cesium carbonate $(725 \mathrm{mg}, 2.22 \mathrm{mmol})$ and phenol derivative $32(0.44 \mathrm{mmol})$ in $50 \mathrm{~mL}$ of DMF was added $\mathrm{BrCH}_{2} \mathrm{CN}$ $(0.03 \mathrm{~mL}, 0.44 \mathrm{mmol})$. The reaction mixture was stirred for $30 \mathrm{~min}$ at rt, poured into $100 \mathrm{~mL}$ of cold $\mathrm{HCl} 1 \mathrm{~N}$, and extracted with AcOEt. The organic phase was dried and evaporated to give the product 33 . White oil (98\% yield). ${ }^{1} \mathrm{H}$ NMR $\left(\mathrm{CDCl}_{3}\right): \delta 2.22(\mathrm{~s}, 6 \mathrm{H}, \mathrm{CH} 3), 4.10$ $\left(\mathrm{s}, 2 \mathrm{H}, \mathrm{CH}_{2}\right), 4.77\left(\mathrm{~s}, 2 \mathrm{H}, \mathrm{CH}_{2} \mathrm{CN}\right), 6.73(\mathrm{~s}, 2 \mathrm{H}, \mathrm{Ar}), 7.15$ (d, $2 \mathrm{H}, \mathrm{J}=$ 8.8, Ar), $8.11(\mathrm{~d}, 2 \mathrm{H}, J=8.8 \mathrm{~Hz}, \mathrm{Ar})$ ppm. Anal. $\left(\mathrm{C}_{17} \mathrm{H}_{16} \mathrm{~N}_{2} \mathrm{O}_{3}\right) \mathrm{C}, \mathrm{H}$, N. \% Calcd: $68.91(\mathrm{C}) ; 5.44(\mathrm{H}) ; 9.45(\mathrm{~N})$. \% Found: $68.65(\mathrm{C}) ; 5.52$ $(\mathrm{H}) ; 9.65(\mathrm{~N})$

N-(4-(4-(Hydroxymethyl)-2-methylbenzyl)-2-isopropylphenyl)acetamide (35). To a solution of trifluoro(4-(hydroxymethyl)-2- methylphenyl)borane salt $(509 \mathrm{mg}, 2.38 \mathrm{mmol})$ in dioxane $/ \mathrm{H}_{2} \mathrm{O}$ 9:1 $(4 \mathrm{~mL})$ was added, under nitrogen atmosphere, $\mathrm{N}$-(4-(bromomethyl)2-isopropylphenyl)acetamide $34(513 \mathrm{mg}, 2.38 \mathrm{mmol})$, cesium carbonate $(2.30 \mathrm{~g}, 7.1 \mathrm{mmol})$, and $\mathrm{PdCl}_{2} \mathrm{dppf}(34.8 \mathrm{mg}, 0.05$ mmol). The resulting mixture was stirred at $95{ }^{\circ} \mathrm{C}$ for $24 \mathrm{~h}$ in a sealed vial. The crude mixture was evaporated and then diluted with water and extracted with DCM. The organic phase was dried over sodium sulfate and the solvent removed. The crude product was chromatographed on a silica gel column, eluting with petroleum ether/ AcOEt (9:1). Brown oil (50\% yield). ${ }^{1} \mathrm{H}$ NMR $\left(\mathrm{CDCl}_{3}\right): \delta \delta 1.20(\mathrm{~d}$, $\left.6 \mathrm{H}, J=6.8 \mathrm{~Hz}, \mathrm{CH}_{3}\right), 2.19\left(\mathrm{~s}, 3 \mathrm{H}, \mathrm{CH}_{3}\right), 2.26\left(\mathrm{~s}, 3 \mathrm{H}, \mathrm{CH}_{3} \mathrm{CO}\right), 2.96-$ $3.03(\mathrm{~m}, 1 \mathrm{H}, \mathrm{CH}), 3.94\left(\mathrm{~s}, 2 \mathrm{H}, \mathrm{CH}_{2}\right), 4.65\left(\mathrm{~s}, 2 \mathrm{H}, \mathrm{CH}_{2}\right), 6.90(\mathrm{dd}$, $1 \mathrm{H}, J=1.6,8.0 \mathrm{~Hz}, \mathrm{Ar}), 7.05-7.09$ (m, 2H, Ar), 7.13 (d, 1H, $J=8.0$ $\mathrm{Hz}, \mathrm{Ar}), 7.17(\mathrm{~s}, 1 \mathrm{H}, \mathrm{Ar}), 7.47(\mathrm{~d}, 1 \mathrm{H}, J=8.0 \mathrm{~Hz}) \mathrm{ppm}$. Anal. $\left(\mathrm{C}_{20} \mathrm{H}_{25} \mathrm{NO}_{2}\right)$ C, H, N. \% Calcd: $77.14(\mathrm{C}) ; 8.09(\mathrm{H}) ; 4.50(\mathrm{~N}) . \%$ Found: $77.39(\mathrm{C}) ; 8.21(\mathrm{H}) ; 4.64(\mathrm{~N})$.

$\mathrm{N}$-(4-(4-Chloromethyl)-2-methylbenzyl)-2-isopropylphenyl)acetamide (36). Compound 36 was synthesized from $35(208 \mathrm{mg}$, $0.67 \mathrm{mmol})$ and $\mathrm{SOCl}_{2}(0.49 \mathrm{~mL}, 6.70 \mathrm{mmol})$ in $\mathrm{CHCl}_{3}(25 \mathrm{~mL})$ following the same procedure described above for the preparation of 21. The crude was used without any further purification. Brown oil (70\% yield). ${ }^{1} \mathrm{H}$ NMR $\left(\mathrm{CDCl}_{3}\right): \delta 1.20\left(\mathrm{~d}, 6 \mathrm{H}, \mathrm{J}=6.8 \mathrm{~Hz}, \mathrm{CH}_{3}\right), 2.20$ $\left(\mathrm{s}, 3 \mathrm{H}, \mathrm{CH}_{3}\right), 2.26\left(\mathrm{~s}, 3 \mathrm{H}, \mathrm{CH}_{3} \mathrm{CO}\right), 2.96-3.03(\mathrm{~m}, 1 \mathrm{H}, \mathrm{CH}), 3.93(\mathrm{~s}$, $\left.2 \mathrm{H}, \mathrm{CH}_{2}\right), 4.57\left(\mathrm{~s}, 2 \mathrm{H}, \mathrm{CH}_{2}\right), 6.90(\mathrm{~d}, 1 \mathrm{H}, J=6.0 \mathrm{~Hz}, \mathrm{Ar}), 7.02-7.09$ (m, 2H, Ar), 7.15 (d, $1 \mathrm{H}, J=8.4 \mathrm{~Hz}, \mathrm{Ar}), 7.19$ (s, 1H, Ar), 7.48 (d, $1 \mathrm{H}, J=8.4 \mathrm{~Hz})$ ppm. Anal. $\left(\mathrm{C}_{20} \mathrm{H}_{24} \mathrm{ClNO}\right) \mathrm{C}, \mathrm{H}, \mathrm{N} . \%$ Calcd: 72.82 (C); $7.33(\mathrm{H}) ; 4.25(\mathrm{~N})$. \% Found: $72.61(\mathrm{C}) ; 7.42(\mathrm{H}) ; 4.13(\mathrm{~N})$.

$\mathrm{N}$-(4-(4-(Cyanomethyl)-2-methylbenzyl)-2-isopropylphenyl)acetamide (37). Compound 37 was synthesized from $36(152 \mathrm{mg}$, $0.46 \mathrm{mmol})$ and $\mathrm{NaCN}(45.3 \mathrm{mg}, 0.92 \mathrm{mmol})$ in $\mathrm{CH}_{3} \mathrm{CN} / \mathrm{H}_{2} \mathrm{O}(1.86$ $\mathrm{mL} / 0.63 \mathrm{~mL}$ ) following the same procedure described above for the preparation of 25 . The crude was used without any further purification. Yellow oil (88\% yield). ${ }^{1} \mathrm{H}$ NMR $\left(\mathrm{CDCl}_{3}\right): \delta 1.20(\mathrm{~d}, 6 \mathrm{H}, J=6.8 \mathrm{~Hz}$, $\left.\mathrm{CH}_{3}\right), 2.19\left(\mathrm{~s}, 3 \mathrm{H}, \mathrm{CH}_{3}\right), 2.25\left(\mathrm{~s}, 3 \mathrm{H}, \mathrm{CH}_{3} \mathrm{CO}\right), 2.96-3.03(\mathrm{~m}, 1 \mathrm{H}$, $\mathrm{CH}), 3.70\left(\mathrm{~s}, 2 \mathrm{H}, \mathrm{CH}_{2}\right), 3.93\left(\mathrm{~s}, 2 \mathrm{H}, \mathrm{CH}_{2}\right), 6.89(\mathrm{~d}, 1 \mathrm{H}, J=8.0 \mathrm{~Hz}$, Ar), 7.03-7.09 (m, 3H, Ar), $7.12(\mathrm{~s}, 1 \mathrm{H}, \mathrm{Ar}), 7.48(\mathrm{~d}, 1 \mathrm{H}, \mathrm{J}=8.0 \mathrm{~Hz}$, Ar) ppm. Anal. $\left(\mathrm{C}_{21} \mathrm{H}_{24} \mathrm{~N}_{2} \mathrm{O}\right) \mathrm{C}, \mathrm{H}, \mathrm{N} . \%$ Calcd: $78.71(\mathrm{C}) ; 7.55(\mathrm{H})$; $8.74(\mathrm{~N})$. \% Found: $78.85(\mathrm{C}) ; 7.41(\mathrm{H}) ; 8.90(\mathrm{~N})$.

Molecular Modeling. All compounds were built, parametrized (Gasteiger-Huckel method), and energy minimized within MOE using MMFF94 force field [MOE: Chemical Computing Group Inc. Montreal. H3A2R7 Canada. http://www.chemcomp.comp]. For all compounds, the protonated form was considered for the in silico analyses.

Docking Studies. Docking studies were performed starting from the in-house homology model of the murine TAAR1 receptor, ${ }^{4}$ built on the X-ray structure of the human $\beta 2$ - adrenoreceptor (PDB ID: 3PDS) ${ }^{17}$ following a protocol we previously discussed exploring the binding mode of other TAAR1 ligands. ${ }^{8,9}$ Briefly, the most promising compounds were docked into the putative ligand binding site by means of the Surflex docking module implemented in Sybyl-X1.0. ${ }^{18}$

Surflex-Dock uses an empirically derived scoring function based on the binding affinities of X-ray protein-ligand complexes. The final total score listed by Surflex-Dock is a weighted sum of nonlinear functions involving van der Waals surface distances between the appropriate pairs of exposed protein and ligand atoms, including hydrophobic, polar, repulsive, entropic, and solvation and crash terms represented in terms of a total score conferred to any calculated conformer. Then, for all the compounds, the best docking geometries (selected on the basis of the SurFlex scoring functions) were refined by ligand/receptor complex energy minimization (CHARMM27) by means of the MOE software.

In Vitro Biological Studies. Reagents. All cell culture reagents and buffers were from Invitrogen (Carlsbad, CA) and Sigma (St. Louis, MO). Coelenterazine $h$ was purchased from Promega (Madison, WI). Plasmid containing the cDNA for the mTAAR1 were generously donated from Hoffman-La Roche. EPAC cAMP BRET sensor was produced as described. ${ }^{19}$

Cell Culture and BRET Experiment. Human embryonic kidney 293 cells (HEK293T) were maintained in Dulbecco's Modified Eagle's 
Medium supplemented with $10 \%(\mathrm{v} / \mathrm{v})$ of FBS, $2 \mathrm{mM}$ L-glutamine, and $0.05 \mathrm{mg} / \mathrm{mL}$ of gentamicin at $37^{\circ} \mathrm{C}$ in a humidified atmosphere at $95 \%$ air and $5 \% \mathrm{CO}_{2}$. Transient transfections were performed $24 \mathrm{~h}$ after cells seeding using Lipofectamine 2000 protocol (Invitrogen). Then $5 \mu \mathrm{g}$ of mTAAR1 and $4 \mu \mathrm{g}$ of EPAC for each milliliter of transfection solution were used for the experiments. For the BRET experiments, the cells were plated, $6 \mathrm{~h}$ after transfection, in poly-Dlysine coated 96-well microplates at a density of 70000 cells per well in phenol red free Minimum Essential Medium containing 2\% of FBS, 10 $\mathrm{mM}$ Hepes, and $2 \mathrm{mM}$ L-glutamine. The cells were then cultured for an additional $24 \mathrm{~h}$. BRET experiment was conducted as already described. ${ }^{7}$ Briefly, for time course experiments, the plate was read immediately after the addition of the agonist and for approximately 20 min. All the compounds were tested for screening at the initial concentration of $10 \mu \mathrm{M}$. Then, for active compounds, a dose response was performed in order to calculate the $\mathrm{EC}_{50}$ values. All the experiments were conducted in the presence of the phosphodiesterase inhibitor IBMX (Sigma) at the final concentration of $200 \mu \mathrm{M}$. Readings were collected using a Tecan Infinite instrument that allows the sequential integration of the signals detected in the 465-505 nm and $515-555 \mathrm{~nm}$ windows using filters with the appropriate bandpass and by using iControl software. The acceptor/donor ratio was calculated as previously described. ${ }^{20}$ Curve was fitted using a nonlinear regression and one site specific binding with GraphPad Prism 5. Data are representative of $4-5$ independent experiments and are expressed as means \pm SEM.

Cell Culture and Glucose Production Evaluation. Human hepatocellular carcinoma cells (HepG2), obtained from American Type Culture Collection (Manassas, VA, USA), were cultured in DMEM supplemented with $10 \%(\mathrm{v} / \mathrm{v})$ fetal bovine serum, $1 \mathrm{mM}$ pyruvate, $100 \mathrm{U} / \mathrm{mL}$ penicillin, and $100 \mathrm{mg} / \mathrm{mL}$ streptomycin at $37^{\circ} \mathrm{C}$ in a humidified atmosphere containing $5 \% \mathrm{CO}_{2}$ and subcultured before confluence. To assess glucose release, HepG2 were seeded into six-well plates $\left(5 \times 10^{5}\right.$ cells/well $)$ and grown to $80 \%$ of confluence with standard medium. As previously described, ${ }^{9}$ before treatment cells were washed twice with PBS and then exposed for $4 \mathrm{~h}$ to test compounds ( 1 and 2) $(0.1,1$, and $10 \mu \mathrm{M})$ in $1 \mathrm{~mL}$ of DMEM base, glucose- and phenol red-free, containing $100 \mathrm{U} / \mathrm{mL}$ penicillin, 100 $\mathrm{mg} / \mathrm{mL}$ streptomycin, and $4 \mathrm{mM}$ L-glutamine, supplemented with 2 $\mathrm{mM}$ sodium pyruvate and $20 \mathrm{mM}$ sodium lactate (glucose production buffer) at $37^{\circ} \mathrm{C}$ in $5 \% \mathrm{CO}_{2}$. Exogenous $\mathrm{T} 1 \mathrm{AM}(0.1,1$, and $10 \mu \mathrm{M})$ was used as control. Control cells were incubated with supplemented DMEM containing DMSO (1-2 $\mu \mathrm{L} /$ well $)$. Cell culture medium was then collected and glucose concentration was measured with a colorimetric glucose assay kit (GAHK-20, Sigma-Aldrich), following manufacturer's instruction. Glucose concentrations were referred to the total protein content (Bradford 1976) of whole HepG2 lysates. Results are expressed as the mean \pm SEM. Differences between groups were analyzed by ANOVA. The threshold of statistical significance was set at $P<0.05$. GraphPad Prism version 6.0 for Windows (GraphPad Software, San Diego, CA, USA) was used for data processing and statistical analysis.

Measurement of Plasma Glycaemia. This investigation and animal use procedure complied with the National Institutes of Health Guide for the Care and Use of Laboratory Animals (NIH Publications no. 80-23, revised 1996) and were approved by the Animal Care Committee of the Department of Pharmacology, University of Florence, in compliance with the European Communities Council Directive of 24 November 1986 (86/609/EEC). All efforts were made to minimize the number of animals used and their suffering.

Glycaemia was monitored in blood collected from the tail vein of 4 $\mathrm{h}$ fasted male mice (CD1 strain, 20-30g, from Envigo, Italy), who had received 1 and $2\left(1.32,4\right.$, and $11 \mu \mathrm{g} \cdot \mathrm{kg}^{-1}$ ip) or saline (ip) ( $n=8$ in each group). Glycaemia was evaluated by a glucorefractometer $15 \mathrm{~min}$ after the ip injections, as described. ${ }^{4}$ Data are expressed as mean \pm SEM of independent experiments. Statistical analysis was performed by one-way ANOVA, followed by Student-Newman-Keuls multiple comparison post hoc test; the threshold of statistical significance was set at $P<0.05$. Data analysis was performed by GraphPad Prism 6.0 statistical program (GraphPad software, San Diego, CA, USA). The acceptor/donor ratio was calculated as previously described. ${ }^{20}$ Curve was fitted using a nonlinear regression and one site specific binding with GraphPad Prism 5. Data are representative of 4-5 independent experiments and are expressed as means \pm SEM.

\section{ASSOCIATED CONTENT}

\section{Supporting Information}

The Supporting Information is available free of charge on the ACS Publications website at DOI: 10.1021/acs.jmedchem.6b01092.

Synthetic pathways and procedures for the preparation of compound 34 and derivatives 11-16, ${ }^{1} \mathrm{H}$ NMR and ${ }^{13} \mathrm{C}$ NMR spectra of final compounds (PDF)

Molecular formula strings (CSV)

\section{AUTHOR INFORMATION}

\section{Corresponding Authors}

*For S.R: phone, +39 050 2219582; fax, +39 050 2219577; Email, simona.rapposelli@farm.unipi.it.

*For G.C.: phone, +39050 2218677; E-mail, g.chiellini@bm. med.unipi.it.

\section{Notes}

The authors declare no competing financial interest.

\section{ACKNOWLEDGMENTS}

We thank Prof. Anna Maria Raspolli Galletti from the Department of Chemistry, University of Pisa (Italy), for allowing us to perform microwave-assisted reactions in her lab, and Prof. Thomas Scanlan for supplying us T1AM. This work was supported by a local grant from the University of Pisa (to G.C. and S.R.) and by the Russian Science Foundation (project N14-25-00065) (to R.R.G.)

\section{ABBREVIATIONS USED}

T1AM, 3-iodothyronamine; T0AM, thyronamine; $\beta$-PEA, $\beta$ phenylethylamine; mTAAR1, murine trace-amine associated receptor 1

\section{REFERENCES}

(1) Scanlan, T. S.; Suchland, K. L.; Hart, M. E.; Chiellini, G.; Huang, Y.; Kruzich, P. J.; Frascarelli, S.; Crossley, D. A.; Bunzow, J. R.; RoncaTestoni, S.; Lin, E. T.; Hatton, D.; Zucchi, R.; Grandy, D. K. 3Iodothyronamine is an endogenous and rapid-acting derivative of thyroid hormone. Nat. Med. 2004, 10, 638-642.

(2) Scanlan, T. S. 3-Iodothyronamine (T(1)AM): a new player on the thyroid endocrine team? Endocrinology 2009, 150, 1108-1111.

(3) Braulke, L. J.; Klingenspor, M.; DeBarber, A.; Tobias, S. C.; Grandy, D. K.; Scanlan, T. S.; Heldmaier, G. 3-Iodothyronamine: a novel hormone controlling the balance between glucose and lipid utilisation. J. Comp. Physiol., B 2008, 178, 167-177.

(4) Chiellini, G.; Nesi, G.; Digiacomo, M.; Malvasi, R.; Espinoza, S.; Sabatini, M.; Frascarelli, S.; Laurino, A.; Cichero, E.; Macchia, M.; Gainetdinov, R. R.; Fossa, P.; Raimondi, L.; Zucchi, R.; Rapposelli, S. Design, synthesis, and evaluation of thyronamine analogues as novel potent mouse Trace Amine Associated Receptor 1 (mTAAR1) Agonists. J. Med. Chem. 2015, 58, 5096-5107.

(5) Chiellini, G.; Rapposelli, S.; Zucchi, R. Synthetic analogues of 3iodothyronamine (tlam) and uses thereof. WO2015151068A1, 2015.

(6) Hoefig, C. Thyroid hormone metabolites in cardiovascular health and disease. In A Symposium on the Occasion of the Centennial Anniversary of Thyroxine Discovery, Delphi, Greece, June 11, 2015; 2015.

(7) Espinoza, S.; Masri, B.; Salahpour, A.; Gainetdinov, R. R. BRET approaches to characterize dopamine and TAAR1 receptor pharmacology and signaling. Methods Mol. Biol. 2013, 964, 107-122. 
(8) Cichero, E.; Espinoza, S.; Gainetdinov, R. R.; Brasili, L.; Fossa, P. Insights into the structure and pharmacology of the human Trace Amine-Associated Receptor 1 (hTAAR1): homology modelling and docking studies. Chem. Biol. Drug Des. 2013, 81, 509-516.

(9) Cichero, E.; Espinoza, S.; Franchini, S.; Guariento, S.; Brasili, L.; Gainetdinov, R. R.; Fossa, P. Further insights into the pharmacology of the human Trace Amine-Associated Receptors: discovery of novel ligands for TAAR1 by a virtual screening approach. Chem. Biol. Drug Des. 2014, 84, 712-720.

(10) Cichero, E.; Espinoza, S.; Tonelli, M.; Franchini, S.; Gerasimov, A. S.; Sorbi, C.; Gainetdinov, R. R.; Brasili, L.; Fossa, P. A homology modelling-driven study leading to the discovery of the first mouse trace amine-associated receptor 5 (TAAR5) antagonists. MedChemComm 2016, 7, 353-364.

(11) Wainscott, D. B.; Little, S. P.; Yin, T.; Tu, Y.; Rocco, V. P.; He, J. X.; Nelson, D. L. Pharmacologic characterization of the cloned human trace amine-associated receptor1 (TAAR1) and evidence for species differences with the rat TAAR1. J. Pharmacol. Exp. Ther. 2007, 320, $475-485$.

(12) Reese, E. A.; Norimatsu, Y.; Grandy, M. S.; Suchland, K. L.; Bunzow, J. R.; Grandy, D. K. Exploring the determinants of trace amine-associated receptor 1's functional selectivity for the stereoisomers of amphetamine and methamphetamine. J. Med. Chem. 2014, 57, 378-390.

(13) Regard, J. B.; Kataoka, H.; Cano, D. A.; Camerer, E.; Yin, L.; Zheng, Y.-W.; Scanlan, T. S.; Hebrok, M.; Coughlin, S. R. Probing cell type-specific functions of $\mathrm{Gi}$ in vivo identifies GPCR regulators of insulin secretion. J. Clin. Invest. 2007, 117, 4034-4043.

(14) Klieverik, L. P.; Foppen, E.; Ackermans, M. T.; Serlie, M. J.; Sauerwein, H. P.; Scanlan, T. S.; Grandy, D. K.; Fliers, E.; Kalsbeek, A. Central effects of thyronamines on glucose metabolism in rats. $J$. Endocrinol. 2009, 201, 377-386.

(15) Manni, M. E.; De Siena, G.; Saba, A.; Marchini, M.; Dicembrini, I.; Bigagli, E.; Cinci, L.; Lodovici, M.; Chiellini, G.; Zucchi, R.; Raimondi, L. 3-Iodothyronamine: a modulator of the hypothalamuspancreas-thyroid axes in mice. Br. J. Pharmacol. 2012, 166, 650-658.

(16) Ghelardoni, S.; Chiellini, G.; Frascarelli, S.; Saba, A.; Zucchi, R. Uptake and metabolic effects of 3-iodothyronamine in hepatocytes. $J$. Endocrinol. 2014, 221, 101-110.

(17) Rosenbaum, D. M.; Zhang, C.; Lyons, J. A.; Holl, R.; Aragao, D.; Arlow, D. H.; Rasmussen, S. G.; Choi, H.-J.; DeVree, B. T.; Sunahara, R. K.; Chae, P. S.; Gellman, S. H.; Dror, R. D.; Shaw, D. E.; Weis, W. I.; Caffrey, M.; Gmeiner, P.; Kobilka, B. K. Structure and function of an irreversible agonist-[bgr] 2 adrenoceptor complex. Nature 2011, $469,236-240$.

(18) Sybyl, X, 1.0; Tripos Inc South Hanley Road, St. Louis, MO 63144, 1699.

(19) Barak, L. S.; Salahpour, A.; Zhang, X.; Masri, B.; Sotnikova, T. D.; Ramsey, A. J.; Violin, J. D.; Lefkowitz, R. J.; Caron, M. G.; Gainetdinov, R. R. Pharmacological characterization of membraneexpressed human trace amine-associated receptor 1 (TAAR1) by a bioluminescence resonance energy transfer cAMP biosensor. Mol. Pharmacol. 2008, 74, 585-594.

(20) Salahpour, A.; Espinoza, S.; Masri, B.; Lam, V.; Barak, L. S.; Gainetdinov, R. R. BRET biosensors to study GPCR biology, pharmacology, and signal transduction. Front. Endocrinol. (Lausanne, Switz.) 2012, 3, 105. 